\title{
Pathological and immunological protection induced by inactivated reverse genetics-based H3N8 equine influenza vaccine candidate in murine model
}

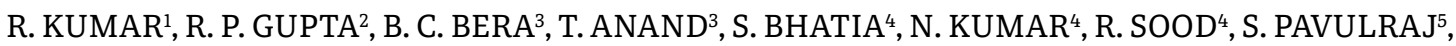 \\ M. K. MATHEW ${ }^{3}$, V. BALENA ${ }^{3}$, S. KARTHIK ${ }^{3}$, R. SANSANWAL ${ }^{3}$, B. N. TRIPATHI ${ }^{2,3}$, N. VIRMANI ${ }^{3 *}$
}

\begin{abstract}
${ }^{1}$ Department of Veterinary Public Health and Epidemiology, Lala Lajpat Rai University of Veterinary \& Animal Sciences, Hisar, Haryana, 125004, India; ${ }^{2}$ Department of Veterinary Pathology, Lala Lajpat Rai University of Veterinary \& Animal Sciences, Hisar, Haryana, 125004, India; ${ }^{3}$ ICAR - National Research Centre on Equines, Hisar, Haryana 125 001, India; ${ }^{4}$ National Institute of High Security Animal Diseases, Bhopal, Madhya Pradesh, 462021, India; ${ }^{5}$ Institut fur Virologie, Freie Universitat, Berlin, Germany
\end{abstract}

Received June 5, 2020; accepted September 16, 2020

\begin{abstract}
Summary. - Equine influenza (EI) is an important viral respiratory disease of equines caused by influenza A virus (IAV). The antigenic drift in IAVs necessitates regular updating and harmonization of vaccine strain with the circulating virus. The reverse genetics-based recombinant viruses could be easy instrument in generating vaccine against circulating virus in a quick and effective manner. Present study has been envisaged to evaluate the immunogenicity and protective efficacy of inactivated recombinant equine influenza virus (rgEIV) vaccine candidate having six segments from H1N1 virus (A/WSN/33/H1N1) and HA (hemaglutinin) and NA (neuraminidase) segments from H3N8 equine influenza virus [(A/eq/ Jammu-Katra/06/08) of clade 2 of Florida sublineage] generated through reverse genetic engineering. $\mathrm{BALB} / \mathrm{c}$ mice were immunized with inactivated rgEIV adjuvanted with aluminium hydroxide gel and challenged with $\mathrm{H} 3 \mathrm{~N} 8$ virus (A/eq/Jammu-Katra/06/08). The protective efficacy was evaluated through serology, cytokine profiling, clinical signs, gross and histopathological changes, immunohistochemistry and residual virus quantification. Immunizations induced robust humoral immune response as estimated through hemagglutination inhibition assay (HAI). The antibodies were isotyped and the predominant subclass was IgG1. The vaccine candidate produced mixed Th1 and Th2 responses through stimulation of IFN- $\gamma$, IL-2, IL-4 and IL-6 expression. Immunization protected mice against challenge as reflected through reduction in clinical signs and body weight loss, early recovery, mild pathological changes (gross and histopathological lesions) as evident through scoring of lesions, low residual virus in nasopharynx and lungs quantified through egg titration and quantitative reverse transcriptase PCR (qRT-PCR). The study demonstrates that inactivated recombinant EIV generated through reverse genetic approach provides equivalent protection to that observed with inactivated whole H3N8 EIV vaccine.
\end{abstract}

Keywords: equine influenza; reverse genetics; vaccine; pathology; murine model

"Corresponding author. E-mail: nvirmani@gmail.com; phone: +91-1662-282508.

Abbreviations: $\mathrm{dpc}=$ days post challenge; $\mathrm{dpi}=$ days post $\mathrm{im}-$ munization; $\mathrm{EI}$ = equine influenza; $\mathrm{EIV}$ = equine influenza virus; $\mathrm{HA}=$ hemagglutinin; $\mathrm{HAI}=$ hemagglutination inhibition; IAV = influenza A virus; NA = neuraminidase; qRT-PCR = quantitative reverse transcriptase PCR; rgEIV = recombinant equine influenza virus; RT-PCR = reverse transcriptase PCR

\section{Introduction}

Equine influenza (EI) is an important viral respiratory disease of equines, caused by influenza A virus (IAV), belonging to the family Orthomyxoviridae, which is a minusstrand virus containing eight RNA segments (Cox et al., 2000; Gildea et al., 2012). In equines, disease is caused by two different subtypes of IAV, i.e. H7N7 and H3N8. How- 
ever, H7N7 virus is no longer in circulation (Garner et al., 2011) and it is H3N8 subtype that continues to circulate and causes disease world over. Currently, the viruses of Florida sub-lineage (clade 1 and 2) are predominant and EIV's belonging to these clades are causing the outbreaks globally.

One of the most effective ways to prevent viral diseases, including equine influenza, is through vaccination. Different types of commercial vaccines are currently available for control of EI, viz. whole inactivated virus, subunit, live attenuated and viral vector-based vaccines (Paillot, 2014). The OIE has mandated the inclusion of currently circulating $\mathrm{HA}$ and NA genes of both clade 1 and clade 2 subtypes of $\mathrm{H} 3 \mathrm{~N} 8$ viruses in EI vaccines (OIE, 2017). Antigenic and genetic drift (the accumulation of point mutations) in the genes encoding for the HA and NA epitopes help virus to evade protective humoral immune system of the host and leads to failure of vaccine (Elton and Cullinane, 2013; Andino and Domingo, 2015). Thus, in order to be effective, equine influenza vaccines require frequent harmonization with inclusion of relevant surface antigens (HA and NA) of circulating EIV. In this context, the reverse genetics platform could serve as a potential tool in accelerating the harmonization process of vaccines by substitution of $\mathrm{HA}$ and NA genes from currently circulating virus in the established backbone in exigencies (Hoffmann et al., 2000; Neumann et al., 2005; Baz et al., 2015; Bhatia et al., 2016). Two live vaccines with recombinant virus - one having HA and NA from A/eq/Georgia/81 in the backbone of A/Ann Arbor/6/60 (H2N2) and the other having all the segments of Florida Clade 1 virus A/equine/Ohio/1/2003 with mutations in PB1 and PB2 to make it attenuated, temperature sensitive and cold adapted - have been tested in murine and ferret and murine and horse model, respectively, and provided adequate protection (Baz et al., 2015; Rodriguez et al., 2018). The present study was thus envisaged to evaluate the protective efficacy of recombinant equine influenza virus (rgEIV) generated through reverse genetic engineering (having six segments from different virus (H1N1/WSN/33) and HA and NA segments from H3N8 of Florida clade 2 sublineage (recommended by OIE to be included in EI vaccine) adjuvanted with aluminium hydroxide. The vaccine candidate was studied for evaluation of the immunological and protective potentials in BALB/c mice, which have been previously successfully utilized as a model for studying pathogenicity of EI(H3N8) infection and immunogenicity and protection studies of whole virus H3N8 vaccine by our group (Pavulraj et al., 2015. 2017).

\section{Materials and Methods}

Ethics and bio-safety and statements. All animal experimentation studies were conducted upon approval of Institute
Animal Ethical Committee(IAEC) (IAEC/16-17/, dated 15.12.2016) and Institute Bio-safety Committee (vide approval no. NRCE/ IBSC/14/252, dated 22.09.2016) of ICAR-National Research Center on Equines (NRCE), India. The guidelines as defined by the Committee for the Purpose of Control and Supervision of Experiments on Animals, Ministry of Environment and Forestry, Government of India were strictly followed for the entire duration of the experiment. All experimental procedures were carried out in BSL-3 facility at ICAR-NRCE, Hisar, Haryana, India. Further, the necessary approval from IAEC was obtained for non-exercising specific procedures to alleviate pain/suffering to the animals following EIV challenge in BALB/c mice. For challenge study, EIV was administered intranasally in mice after applying anesthesia with Xylazine and Ketamine mixture (10 mg of xylazine $+50 \mathrm{mg}$ of ketamine @ $100 \mathrm{mg} / \mathrm{kg}$ body weight) intra-peritoneally. Before experiment, mice were acclimatized and were provided feed and water ad libitum during complete period of the study. The special permission was obtained from IAEC for the humane sacrifice of mice employing standard method of cervical dislocation under the influence of anesthesia (10 mg of xylazine + $50 \mathrm{mg}$ of ketamine @ $100 \mathrm{mg} /$ $\mathrm{kg}$ body weight intra-peritoneally). The bio-hazard materials were safely disposed through the service from a private partner (Synergy Waste Management [p] limited, Hisar, India).

Equine influenza virus (EIV). The EIV AA/eq/JammuKatra/06/08 (H3N8)\} belonging to clade 2 of Florida sublineage isolated from the EI outbreak in India in 2008-2009 (Virmani et al., 2010) and maintained at ICAR-NRCE, Hisar, was used in this study. The virus was propagated in 9-11-day-old embryonated hen's eggs and purified by sucrose gradient centrifugation method (Laver and Valentine, 1969). Titration of EIV was done by calculation of $50 \%$ egg infectious dose $\left(\operatorname{EID}_{50}\right)$ as per standard protocol. Reed and Muench method (Reed and Muench, 1938) was used to calculate $50 \%$ end point result, which was expressed as $\mathrm{EID}_{50^{\circ}}$.

Inactivated rgEIV. rgEIV generated previously by employing reverse genetics approach, available with ICAR-NRCE, Hisar, Haryana was used for this study. The rgEIV was propagated and purified as described previously for EIV (Pavulraj et al., 2015) and inactivated with $0.2 \%$ formalin for three days at $4^{\circ} \mathrm{C}$ with gentle shaking. The viral protein content of rgEIV was quantified by standard Bradford assay (Sigma). The required amount of inactivated ultra-purified rgEIV was diluted in sterile PBS and mixed with aluminium hydroxide in 1:1 ratio such that each mouse was immunized with $15 \mu \mathrm{g}$ viral proteins.

$B A L B / c$ mice and design of animal experimentation. The study was carried out in 4-5-week-old BALB/c mice $(n=170)$ procured from NCLAS, National Institute of Nutrition, Hyderabad. The mice were allowed to acclimatize in quarantine area of Microbial Containment Laboratory (BSL-3 facility) for a period of 10 days before start of experiments. Mice were provided ad libitum feed and water for the entire duration of the experiment. As the protection studies were required to be conducted based upon 
Table 1. Immunization and challenge schedule of BALB/c mice

\begin{tabular}{|c|c|c|c|c|c|}
\hline \multirow[b]{2}{*}{ Group } & \multicolumn{3}{|c|}{ Vaccination } & \multirow{2}{*}{$\begin{array}{l}\text { EIV challenge } \\
\text { (day 42) }\end{array}$} & \multirow[b]{2}{*}{ Purpose } \\
\hline & $\begin{array}{c}\text { Primary immunization } \\
\text { (day 0) }\end{array}$ & $\begin{array}{l}\text { First booster } \\
\text { (day 21) }\end{array}$ & $\begin{array}{l}\text { Second booster } \\
\text { (day 35) }\end{array}$ & & \\
\hline A & Yes & Yes & Yes & No & Immunized negative control \\
\hline $\mathrm{B}$ & Yes & Yes & Yes & Yes & Protective efficacy testing \\
\hline $\mathrm{C}$ & No & No & No & Yes & Unimmunized positive control \\
\hline $\mathrm{D}$ & No & No & No & No & Negative control \\
\hline
\end{tabular}

clinical signs and detailed examination of tissues (gross as well as histopathology), the use of analgesics would have masked or alleviated the responses and thus a special permission for the humane sacrifice was obtained from IAEC. Mice were sacrificed at 21 and 35 days post immunization (dpi) and after challenge at seven different intervals, viz. 42, 43, 45, 47, 49, 52 and $56 \mathrm{dpi}$ or $0,1,3,5,7,10$ and 14 days post challenge (dpc). Mice studies were planned by vaccinating the animals with rgEIV followed by challenge with wild EIV. For this, BALB/c mice were randomly divided into two groups 1 and 2 (further split into four groups, viz. A, B, C and D). Prior to challenge studies, group A and $B$ mice were housed together $[n=85(A+B)]$ and also those belonging to group $C$ and $D[n=85(C+D)]$. Group $A$ and $B$ mice were vaccinated intramuscularly with $15 \mu$ g of inactivated rgEIV adjuvanted with aluminium hydroxide followed by two boosters on $21^{\text {st }}$ and $35^{\text {th }}$ dpi. Group C and D were mock vaccinated with sterile PBS. Five mice each were randomly selected (to avoid bias) from pooled groups of $A$ and $B$ as well as from $C$ and $D$ for monitoring the immune responses. Prior to challenge on $42 \mathrm{dpi}$, mice for group A, B, C and D were separated and each comprised of 35 mice. Group $B$ and $C$ were challenged intranasally with wild EIV $\left\{\right.$ A/eq/Jammu-Katra/06/08(H3N8)\} @ 107.24 EID $_{50}$ on 42 dpi (Table 1 and Fig. 1).

Serology. Humoral immune responses after vaccination and challenge were analyzed employing hemagglutination inhibition (HAI) test as per OIE protocols (OIE, 2017) and indirect ELISA of serum samples from each group, which were collected in sterile vials on $21,35,42$ 43, 45, 47, 49, 52 and 56 dpi. For HAI test, $4 \mathrm{HA}$ units of EIV antigen \{(A/equine/Jammu-Katra/06/08 (H3N8)\} were used and the test sera were heat inactivated at $56^{\circ} \mathrm{C}$ for $30 \mathrm{~min}$ after treatment with $0.016 \mathrm{M}$ potassium periodate to neutralize nonspecific hemagglutinins and excess periodate was removed by $3 \%$ glycerol.

For indirect ELISA test, ELISA plates (MaxiSorp, NUNC) were pre-coated with 1048 HA units of EIV (A/Katra-Jammu//06/08) with 1:800 dilution. After blocking with $7.5 \%$ skim milk, different dilutions of test sera starting at 1:8,000 were added and incubated at $37^{\circ} \mathrm{C}$ for one hour. Following three washings, HRPconjugated goat-anti mouse antibody (1:2,500 dilution; Sigma Aldrich) was added. Color reaction was detected using 3, 3", 5, 5 ' tetramethylbenzidine (Sigma Aldrich) as substrate. Absorbance was recorded at $450 \mathrm{~nm}$ in ELISA reader and titer was

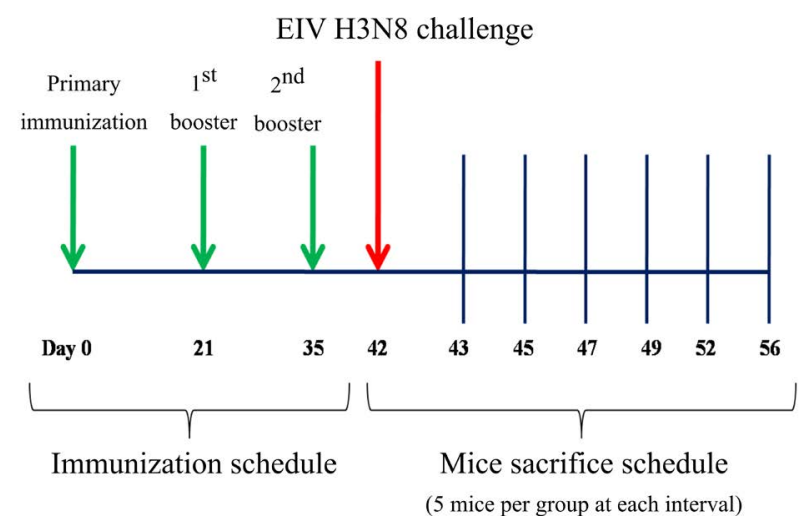

Fig. 1

Experimental design, immunization and challenge schedule Primary, $1^{\text {st }}$ boost, $2^{\text {nd }}$ boost immunization and challenge with H3N8 EIV was conducted on $0,21^{\text {st }}, 35^{\text {th }}$ and $42^{\text {nd }}$ days, respectively. Following challenge at $42 \mathrm{dpi}$, mice were sacrificed on day 43 (1 dpc), 45 (3 $\mathrm{dpc}), 47$ (5 dpc), 49 (7 dpc), 52 (10 dpc) and 56 (14 dpc).

expressed as $\log _{10}$ value of highest dilution of serum, at which the absorbance was equal or greater than twice the baseline value of negative control.

Serum antibody isotyping. The mouse monoclonal antibody isotyping reagents - ISO2 (Sigma Aldrich) were used for detection of EIV-specific antibodies (IgG1, IgG2a, IgG2b, IgG3, IgM and IgA) by indirect ELISA performed on duplicate test serum samples. Briefly, ELISA plates (MaxiSorp, NUNC) were coated overnight with H3N8 EIV- A/eq/Katra-Jammu/06/08 at $4^{\circ} \mathrm{C}$ and blocked with $7.5 \%$ skim milk. Diluted test sera in duplicate (beginning from 1:500 dilution) were added into wells and incubated at $37^{\circ} \mathrm{C}$ for $1 \mathrm{~h}$. Isotype-specific reagents (1:1000 in PBS) were added following washing with PBS containing $0.05 \%$ Tween-20 and incubated at $37^{\circ} \mathrm{C}$ for $1 \mathrm{~h}$. Finally, peroxidase labelled rabbit anti-goat IgG (1:30,000) were added to all wells and detected by $3,3^{\prime}, 5,5^{\prime}$ tetramethylbenzidine substrate through reading plate absorbance at $450 \mathrm{~nm}$ in ELISA reader.

Estimation of cytokines gene expression by quantitative reverse transcriptase - polymerase chain reaction ( $q R T-P C R)$. Tissue samples (spleen and lungs) were collected in RNA stabilization solution (Qiagen, Valencia, CA) and total RNA was 
(a)

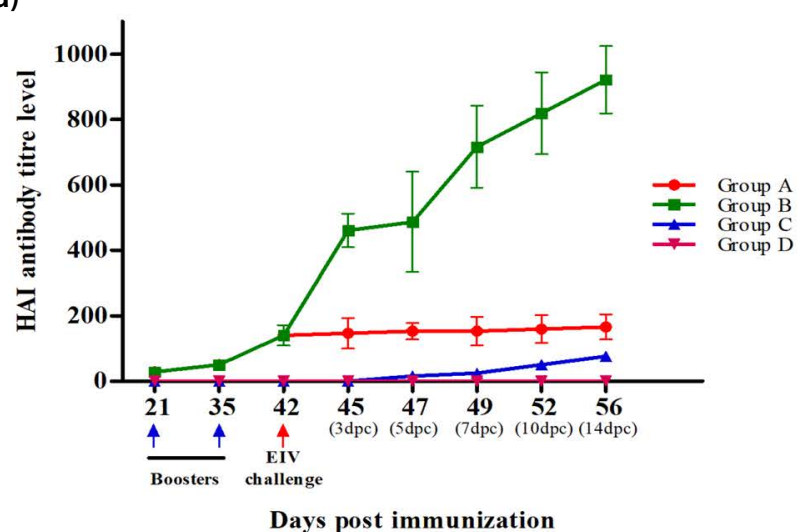

(b)

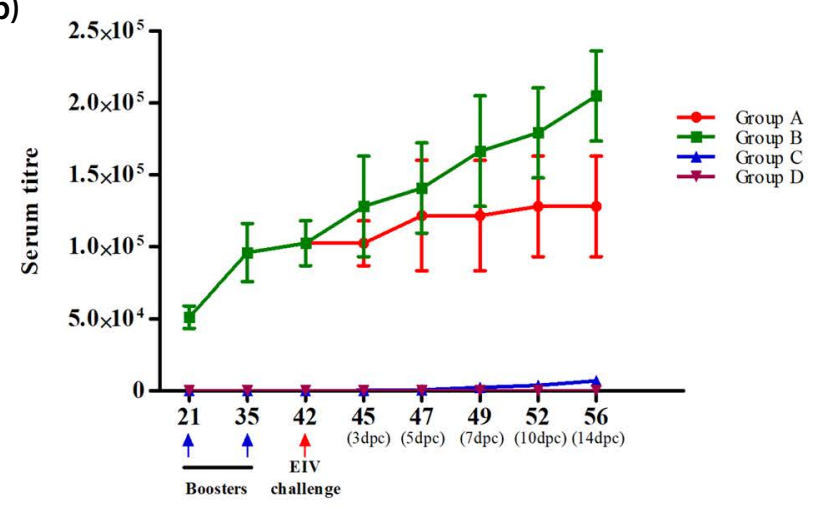

Days post immunization

Fig. 2

Antibody titers of BALB/c mice from various groups following immunization and challenge with EIV

(a) Mean HAI titres. (b) Serum ELISA antibody titers. Each value represents mean \pm SEM $(n=5)$. Significance between groups evaluated by two-way ANOVA, Bonnferoni post hoc test.

purified from tissue (25 mg) homogenates using the RNeasy mini kit (Qiagen, Valencia, CA) following manufacturer's instructions. The complementary DNA (cDNA) was synthesized using the High Capacity cDNA Reverse Transcriptase Kit (\# Cat no.4368814, Applied Biosystems) using random primer as per the manufacturer's instruction. The reaction mixture $(25 \mu \mathrm{l})$ contained $1 \mu \mathrm{g}$ RNA, $2.5 \mu \mathrm{l} 10 \mathrm{x}$ RT buffer, $0.8 \mu \mathrm{l} 25 \mathrm{x}$ dNTP (100 $\mathrm{mM}$ ), $2.0 \mu \mathrm{l}$ 10x random primer, $0.5 \mu \mathrm{l}$ RNase Inhibitor and $1.0 \mu \mathrm{l}$ MultiScribe Reverse Transcriptase (50 U/ $\mu \mathrm{l})$. The relative expressions of cytokines were measured using TaqMan Cytokine Gene Expression kits (IFN- $\gamma$ : Mm01168134_m1, IL-2: Mm00434256_m1, IL-4: Mm00445259_m1, IL-6: Mm00446190_ m1, GAPDH: 99999915_g1; Applied Biosystems, Foster City, CA, USA) in a real-time PCR system (StepOne, Applied Biosystems) using comparative $\mathrm{Ct}$ method and Sequence Detection software v.1.2.2 (Applied Biosystems). The results of cytokine gene expressions were normalized to the GAPDH gene. The gene expression was determined as fold increase given by the formula: Fold change $=2^{-\mathrm{DDC}}{ }_{\mathrm{T}}$ where, $\mathrm{DC}_{\mathrm{T}}$ is the difference in threshold cycles for target and endogenous control and DDCt $=[(\mathrm{Ct}$ of target gene in treatment sample) - (Ct of GAPDH in treatment sample) - - (Ct of target gene in control sample) - (Ct of GAPDH in control sample)]. Hence, ${ }^{-D D} C_{T}$ is the difference between $\mathrm{DC}_{\mathrm{T}}$ values for immunized/challenged and control group. The IFN- $\gamma$ mRNA expression was estimated before vaccination (21,35 and $42 \mathrm{dpi}$ ) and after challenge (3,5,10 and $14 \mathrm{dpc})$. Other cytokines, viz. IL-2, IL-4 and IL-6, mRNA expressions were estimated on 42 dpi and after challenge ( $3,5,10$ and $14 \mathrm{dpc})$. The cytokine gene expression was depicted as the mean fold changes.

Clinical signs and postmortem examination. Mice were daily checked for clinical signs such as hunching in corners of eyes, crouching, ruffled fur and other signs. Body weight was recorded for all mice on daily basis at a fixed time throughout the experiment. Mice belonging to different groups were euthanized humanely by cervical dislocation under anesthesia of Xylazine and Ketamine. Five mice were assigned to each group for each interval. Gross lesions were recorded and parts of organs viz., trachea, lungs, nasal turbinates and spleen were collected for various studies. Gross lung lesions were scored as previously described (Pavulraj et al. 2017) and criteria considered were area of consolidation (1-3 grades for $<1 \mathrm{~mm}^{2}, 2-3 \mathrm{~mm}^{2}$ and $<3 \mathrm{~mm}^{2}$ ), +1 grade for congestion of lung parenchyma and +1 grade for gray discolouration of lung parenchyma giving a maximum possible score of 5 .

Histopathological examination and immunohistochemical localization of antigen. Tissue samples collected in buffered formalin were fixed and processed further following standard protocol. Stained slides were examined under light microscope (Nikon model-80i). Grading of histopathological lesions (0 to 5) for different groups at different intervals was done as per the criteria followed previously (Pavulraj et al., 2015), viz. neutrophilic/lymphocytic/macrophages infiltration in interstitial spaces, interstitial consolidation and edema, perivascular infiltration, peribronchial infiltration, extent of bronchial lesions, necrotic lesions in lung parenchyma and overall intensity of the lesion. Indirect immunoperoxidase test (IIPT) was performed for localization of antigen distribution in nasal turbinate, trachea and lung of mice belonging to different groups at different intervals as per the protocol described earlier (Virmani et al., 2010).

Virus quantification. Nasal wash and lung tissue collected from mice at different time intervals after challenge were examined for the virus load. For this, $25 \mathrm{mg}$ of lung tissue collected in $150 \mu \mathrm{l}$ of cold PBS (supplemented with antibiotic and antifungal solution) was homogenized using mechanical homogenizer. Lung homogenate was subjected to freeze/thaw to release any 
(a)

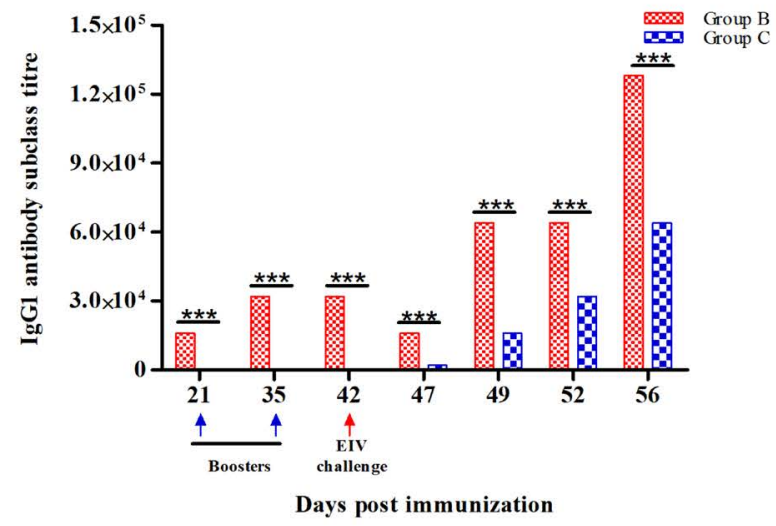

(c)

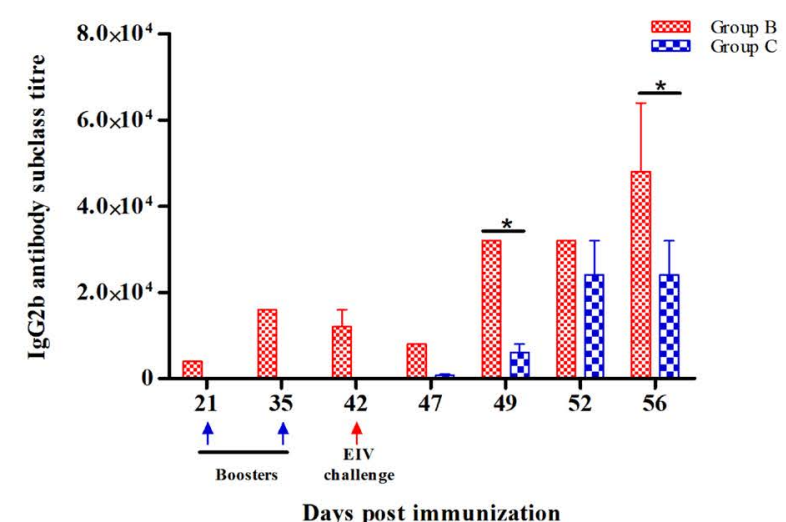

(e)

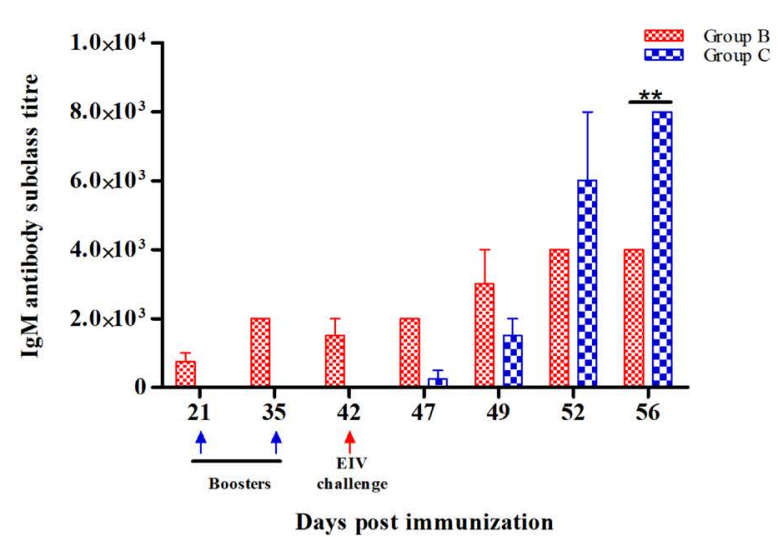

(b)

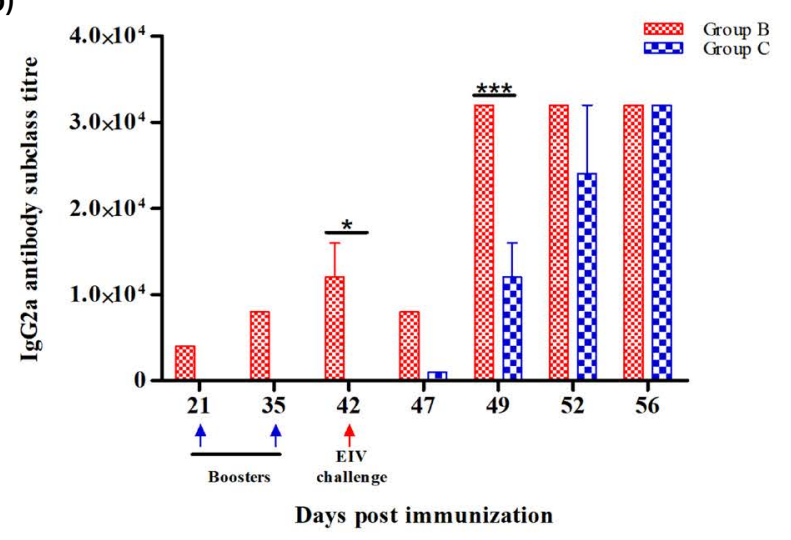

(d)

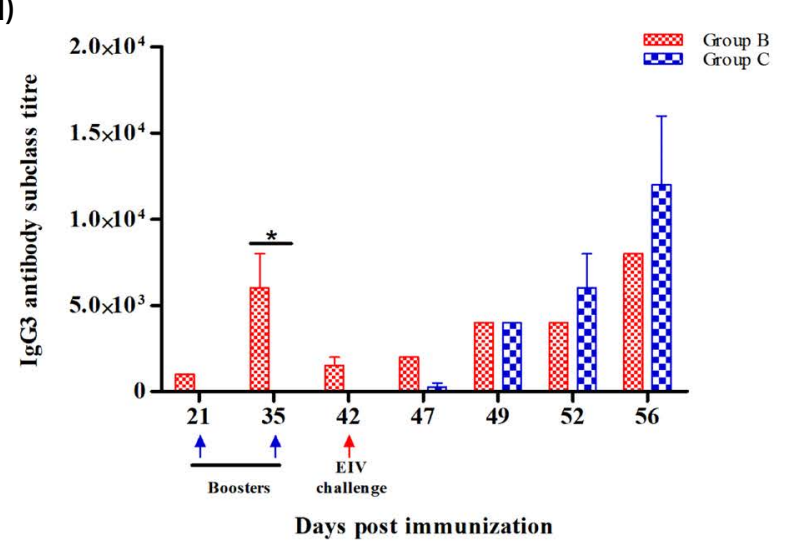

(f)

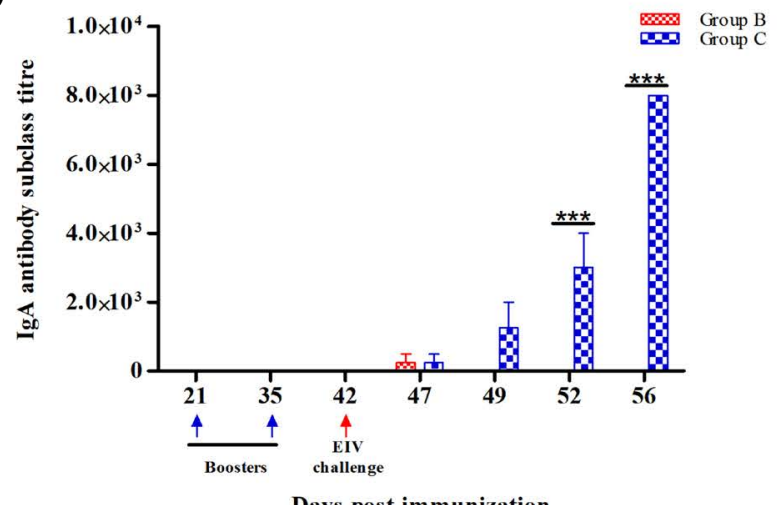

Fig. 3

Antibody subtype in response to immunization and challenge with EIV

(a) Serum IgG1 antibody subclass response. (b) Serum IgG2a antibody subclass response. (c) Serum IgG2b antibody subclass response. (d) Serum IgG3 antibody subclass response. (e) Serum IgM antibody subclass response. (f) Serum IgA antibody subclass response. Each value represents mean \pm SEM $(n=5)$. ***indicates significant increase $(p<0.001)$ and ${ }^{* *} p<0.01$ and ${ }^{*} p<0.05$ between groups in two-way ANOVA, Bonnferoni post hoc test.

intracellular virus and centrifuged to get clear supernatant. One hundred microliters of ten-fold serial dilutions of lung homogenates were inoculated in 9-11-day-old embryonated egg per egg in triplicates. Similarly, virus titration for nasal wash was determined by inoculating $100 \mu \mathrm{l}$ of 10 -fold serial dilutions of pooled nasal washing in embryonated eggs as explained above for lung tissue. Hemagglutination assay was performed in harvested allantoic fluid. EIV titer was calculated by Reed and Muench (1938) method and expressed as EID ${ }_{50}$ per gram of lung tissue or per $\mathrm{ml}$ of nasal wash solution. 
Quantification of virus load by TaqMan qRT-PCR. The viral RNA was isolated from pooled lung homogenate $(25 \mathrm{mg})$ and tracheal washing $(140 \mu \mathrm{l})$ of various groups of mice at different time intervals using QIAamp ${ }^{\circledR}$ Viral RNA Mini kit (Qiagen, Valencia, CA) as per the manufacturer's instructions. The TaqMan probebased qRT-PCR was performed for quantification of EIVs. The single-step TaqMan qRT-PCR assay standardized earlier in the laboratory following the methodology as described previously (Lu et al., 2009) using primers targeting the conserved region of nucleoprotein (NP) gene of influenza A virus was employed. The TaqMan qRT-PCR assay was carried out in a single reaction tube using the TaqMan ${ }^{\circledR}$ Fast Virus 1-Step Master Mix (Applied Biosystems, Foster City, CA, USA) in Step-One Real Time PCR Machine (Applied Biosystems) as per the manufacturer's instructions. The reporter dye-FAM was incorporated in the synthesized probe for compatibility of the emission spectra detected in the Real Time PCR machine. Four standards of known quantity of in-vitro transcribed (IVT) RNA of cloned NP gene were included in every reaction set up for quantification of EIVs. The reaction mixture $(10 \mu \mathrm{l})$ for each sample contained $2.5 \mu 1$ 4x TaqMan ${ }^{\circledR}$ Fast Virus 1 - Step Master Mix, $0.9 \mu$ l of each forward and reverse primers, $0.5 \mu \mathrm{l} \mathrm{EqFlu} \mathrm{NP} \mathrm{Prb/FAM}(5 \mu \mathrm{M})$, $3.2 \mu \mathrm{l}$ nuclease free water and $2.0 \mu \mathrm{l}$ RNA. The Real-Time PCR cycling conditions included holding for $5 \mathrm{~min}$ at $50^{\circ} \mathrm{C}$ and $20 \mathrm{~s}$ at $95^{\circ} \mathrm{C}$ followed by 40 cycles comprising of $95^{\circ} \mathrm{C}$ for $3 \mathrm{~s}$ and at $60^{\circ} \mathrm{C}$ for $30 \mathrm{~s}$. Automatic threshold for the $\mathrm{Ct}$ was selected and the reaction efficiency $>95 \%, \& R^{2}$ value $>0.98$ of standard curve was considered for evaluation.

Statistical analysis. The data were expressed as means \pm SEM. Statistical analysis was performed using GraphPad PRISM ${ }^{*}$ software version 5.04. The two-way ANOVA followed by Bonferroni post-hoc tests was used to compare replicate means by row. A value of $\mathrm{p}<0.05$ was considered statistically significant.

\section{Results}

\section{Humoral antibody response}

Inactivated rgEIV adjuvanted with aluminium hydroxide mice (group B) showed sero-conversion after 21 dpi with mean serum HAI antibody titer of $28.8 \pm 3.20$, which progressively increased to $51.2 \pm 7.85$ ( $1^{\text {st }}$ booster) and $140.8 \pm 31.35$ ( $2^{\text {nd }}$ booster). Following challenge, a sharp increase in HAI titers was noticed, which persisted throughout the experiment and was significantly higher $(\mathrm{p}<0.001)$ in comparison to groups A and C. At the end of the experiment ( $14 \mathrm{dpc}$ ), mean HAI antibody titer of group B was $921.6 \pm 102.40$, which was approximately six folds higher than on the day of challenge $(140.8 \pm 31.35)$. From 5 dpc onward, a rapid increase in HAI titers was observed in group $C$ that reached to $76.8 \pm 12.8$ at $14 \mathrm{dpc}$ (Fig. 2a). Group $\mathrm{D}$ mice remained seronegative throughout the period of the experiment.
ELISA antibody titer in vaccinated mice following primary immunization resulted in mean antibody titer $51200 \pm 7838.37$ on $21 \mathrm{dpi}$, which increased to $102400 \pm 15676.73$ after booster vaccination (on $42 \mathrm{dpi}$ ). Following challenge, group B showed spike in antibody titer, while group $C$ did not show any titers on the day of challenge but slowly rose to $7040 \pm 1567.67$ by $14 \mathrm{dpc}$ (Fig. 2b).

Serum antibody subtype in response to immunization and challenge

The optimized immune response was further characterized through estimation of immunoglobin subclasses by isotyping ELISA. Primary immunization induced detectable titers of IgG1, IgG2a, IgG2b, IgG3 and IgM in serum. The second and third immunization boosted the antibody titers and mean antibody titers reached to $32,000 \pm 0,12,000 \pm 4,000,12,000 \pm 4,000,1,500 \pm 500$ and $1,500 \pm 500$, respectively for IgG1, IgG2a, IgG2b, IgG3 and IgM at $42 \mathrm{dpi}$ (Fig. 3a-f). No responses were detectable for IgA antibodies. A dramatic upsurge ( $p>0.05)$ in titers of all subclasses of antibodies were witnessed in immunized mice (group B) following H3N8 EIV challenge on $3 \mathrm{dpc}$ onwards and recorded maximum on $14^{\text {th }} \mathrm{dpc}$ (titers were $128,000 \pm 0,32,000 \pm 0,48,000 \pm 16,000,8,000 \pm 0$ and $4,000 \pm 0$ for IgG1, IgG2a, IgG2b, IgG3 and IgM, respectively). At the same time, group $\mathrm{C}$ mice showed mild antibody titers (detected only $5 \mathrm{dpc}$ onward) with peak on $14 \mathrm{dpc}$.

\section{Evaluation of cytokine gene expression}

The immunized mice showed increased expression level of transcripts of IFN $-\gamma(64 \pm 10$ folds $)$, IL-2 $(8.06 \pm 0.98)$ and IL-6 (4.54 \pm 0.79$)$ mRNA in spleen; whereas only IL-6 expression $(8.6 \pm 0.82)$ was increased in lung at $42 \mathrm{dpi}$. Upon challenge with wild EIV, IL-4 expression was increased (1.6, 1.3, 3.6 and 4.7 folds at 3, 5, 10 and $14 \mathrm{dpc}$, respectively) in spleen. In lungs, group B showed IFN- $\gamma$ expression fold increase of $169 \pm 10$ on $3 \mathrm{dpc}$, which fell down gradually to $84 \pm 8$ on $14 \mathrm{dpc}$, while in spleen fold changes decreased to $31 \pm 3$ at 3 dpc. The IL- 6 level increased $(5.46 \pm 0.29)$ at $3 \mathrm{dpc}$ in spleen, but decreased in lung $(1.36 \pm 0.62)$ (Fig. 4a-f).

The rgEIV vaccine immunization protects mice from development of clinical signs and body weight reduction following wild EIV H3N8 challenge

Post EIV challenge, variation in clinical signs was clearly demarcated among different groups. None of the mice from group B showed any signs of illness. There was no adverse effect on body weight in group B mice 
(a)

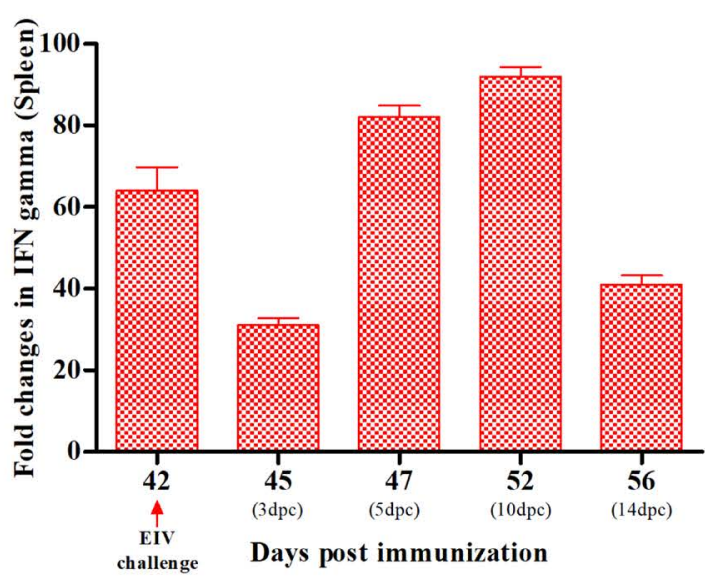

(c)

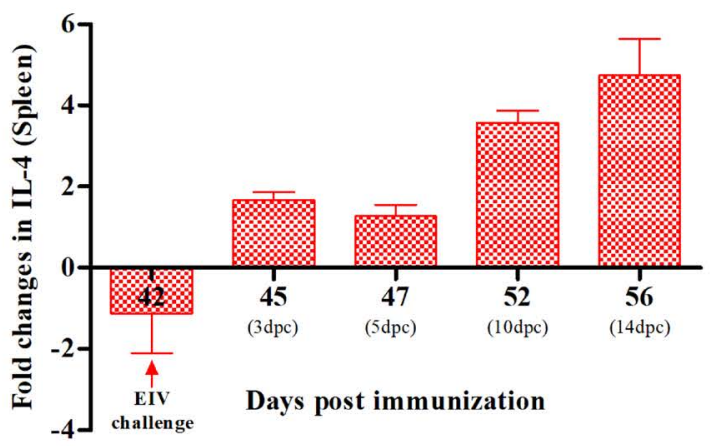

(e)

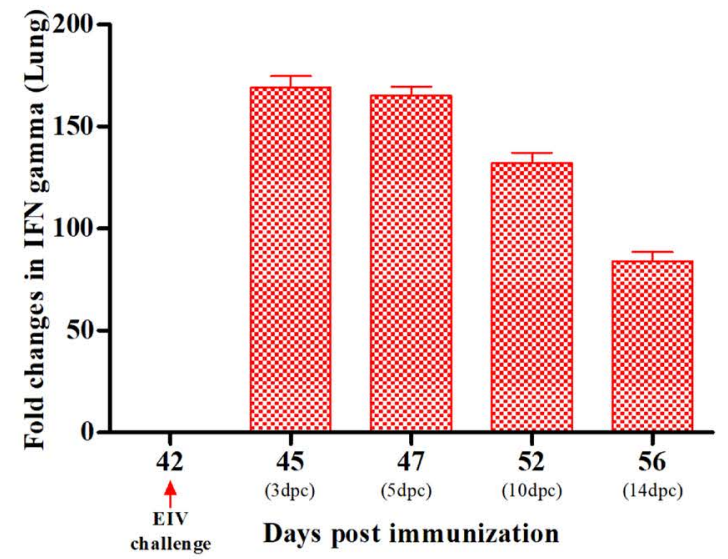

(b)

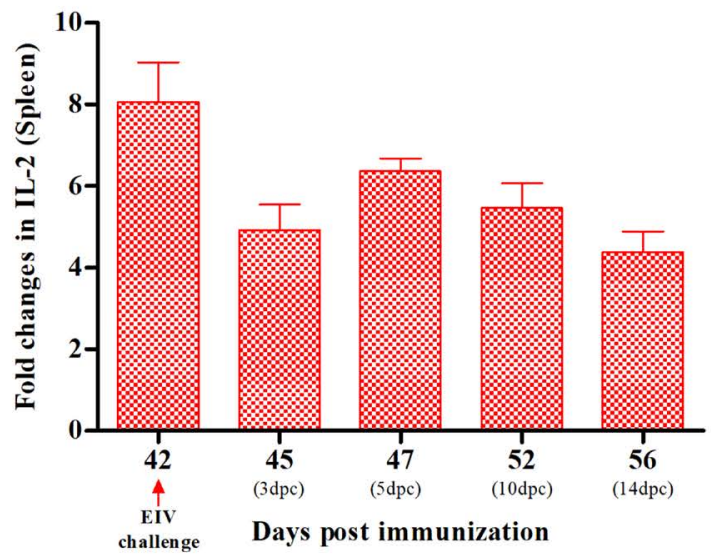

(d)

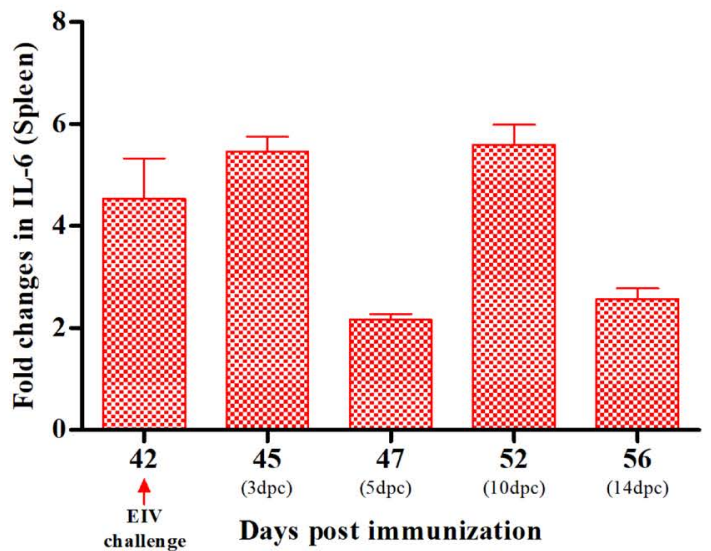

(f)

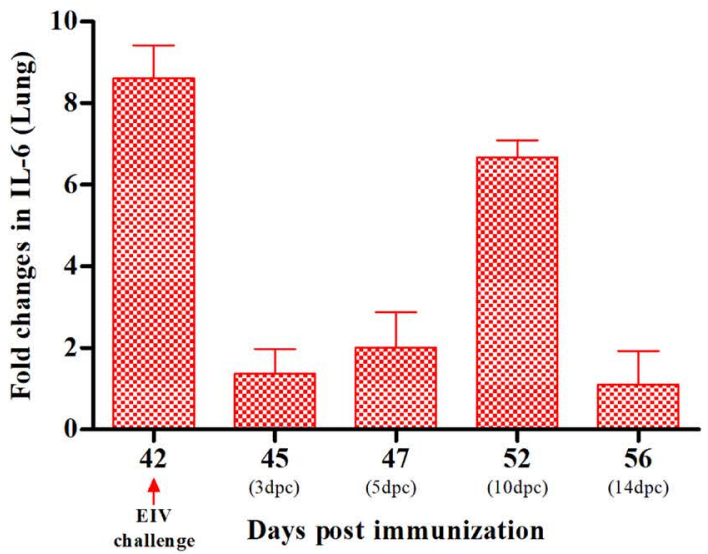

Fig. 4

Relative quantification of cytokine gene expression in spleen and lung of immunized animals

(a-d) Mean fold changes in expression of IFN- $\gamma$, IL-2, IL-4 and IL- 6 in spleen of immunized challenged mice. (e, f) Mean fold changes in expression of IFN- $\gamma$ and IL-6 in lung of immunized challenged mice. Each value represents mean $\pm \operatorname{SEM}(n=5)$. 
(a)

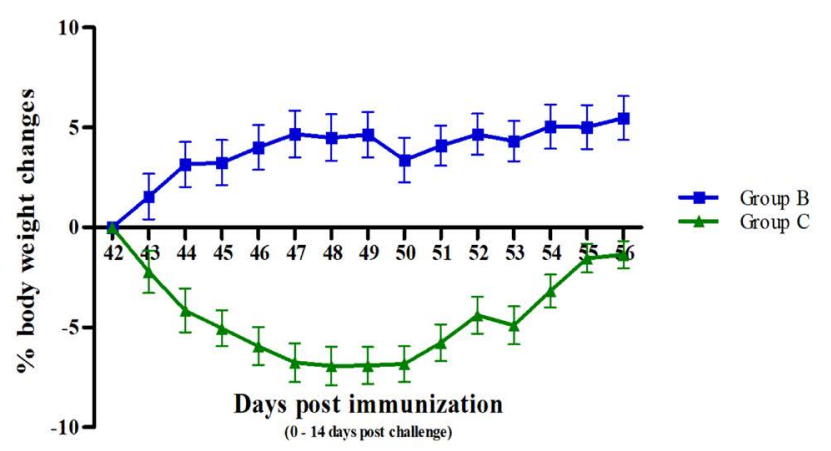

(b)

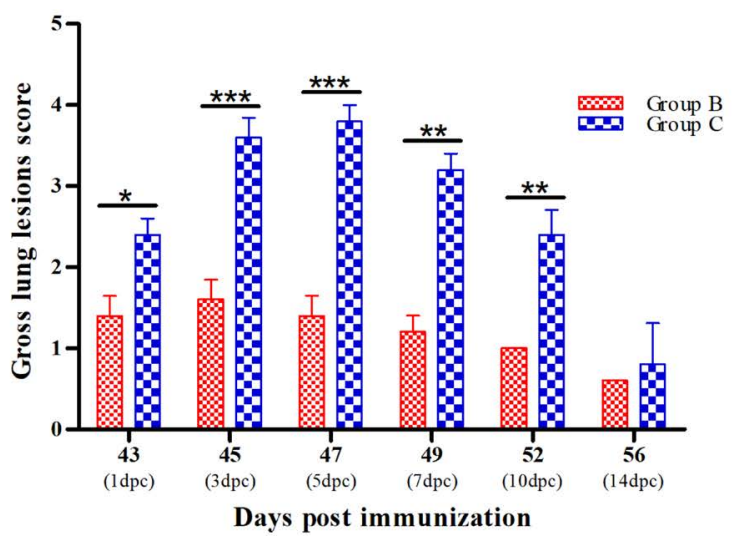

Fig. 5

The rgEIV immunization conferred robust protections against challenge with EIV (H3N8) in BALB/c mice

(a) Percent body weight change in mice of various groups at different intervals following challenge with EIV. Each value represents mean $\pm \operatorname{SEM}(\mathrm{n}=5)$. (b) Mean gross lung lesion scores of group $\mathrm{B}$ and $\mathrm{C}$ at different intervals after challenge with EIV. Each value represents mean \pm SEM $(\mathrm{n}=5)$. ${ }^{* *}$ indicates significant decrease $(\mathrm{p}<0.001)$ and ${ }^{* *} \mathrm{p}<0.01$ and ${ }^{*} \mathrm{p}<0.05$ between groups in two-way ANOVA, Bonnferoni post hoc test.

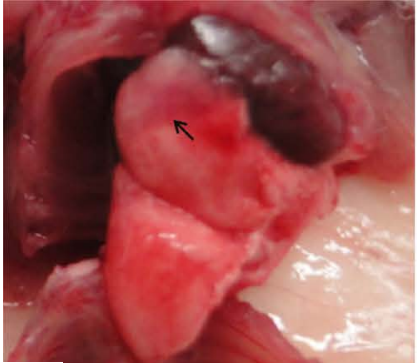

(a)

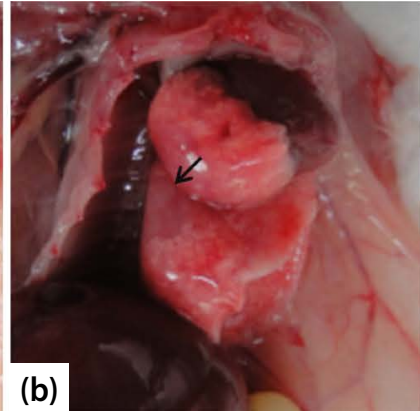

(b)

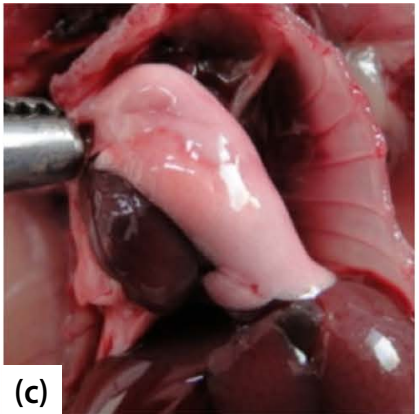

Fig. 6

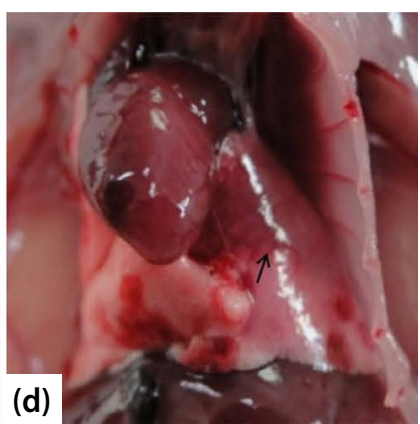

(d)

Protection of lesions in rgEIV immunized BALB/c mice against EIV challenge

(a) Lung from group C mouse at $1 \mathrm{dpc}$, showing congestion in hilus region and apical lobe (arrow). (b) Lung from group C mouse at $3 \mathrm{dpc}$, showing red hepatization (arrow). (c) Lung from group B mouse at $5 \mathrm{dpc}$, showing apparently healthy normal appearance. (d) Lung from group C mouse at $5 \mathrm{dpc}$, showing severe grey hepatization in anterior region (arrow).

whereas, positive control (group C) mice started showing signs of anorexia, reduced feed and water intake, crouching at corners, ruffled coat, polypnea, respiratory distress, weight loss, inactivity and accumulation of discharge around the corners of eyes and continuous significant body weight loss from $2 \mathrm{dpc}$, which intensified by $3 \mathrm{dpc}$ with peak at $6 \mathrm{dpc}(-6.92 \% \pm 0.96)$ and thereafter, the trend was towards recovery in body weight from 8 dpc onwards. None of the mice regained their original body weight till the end of the experiment (Fig. 5a). Signs persisted or became even more pronounced till $7^{\text {th }} / 8^{\text {th }}$ $\mathrm{dpc}$ followed by a decline and returned to normal by 14 dpc. No mortality was observed during the entire period of experiment.
Protection as adjudged through reduction in pathological lesions by rgEIV vaccine candidate in mice following challenge with wild virus

Lesions induced by challenge EIV were restricted to respiratory tract. Gross and histopathological lesions were significantly less intense in vaccinated mice as compared to the unvaccinated mice. Vaccinated and challenged mice (group B) did not show any significant gross lesions except mild congestion on 3 and $5 \mathrm{dpc}$ (Fig. 6c). Group C mice revealed moderate to severe congestion of both left and right lobes of lungs starting from the hilus region and apical lobe at $1 \mathrm{dpc}$ (Fig. 6a) with regions of red hepatization in hilus measuring approximately $2 \times 2.5-3$ $\mathrm{mm}$ at $3 \mathrm{dpc}$ (Fig. $6 \mathrm{~b}$ ) and grey hepatization $(>5 \times 6 \mathrm{~mm}$ ) 

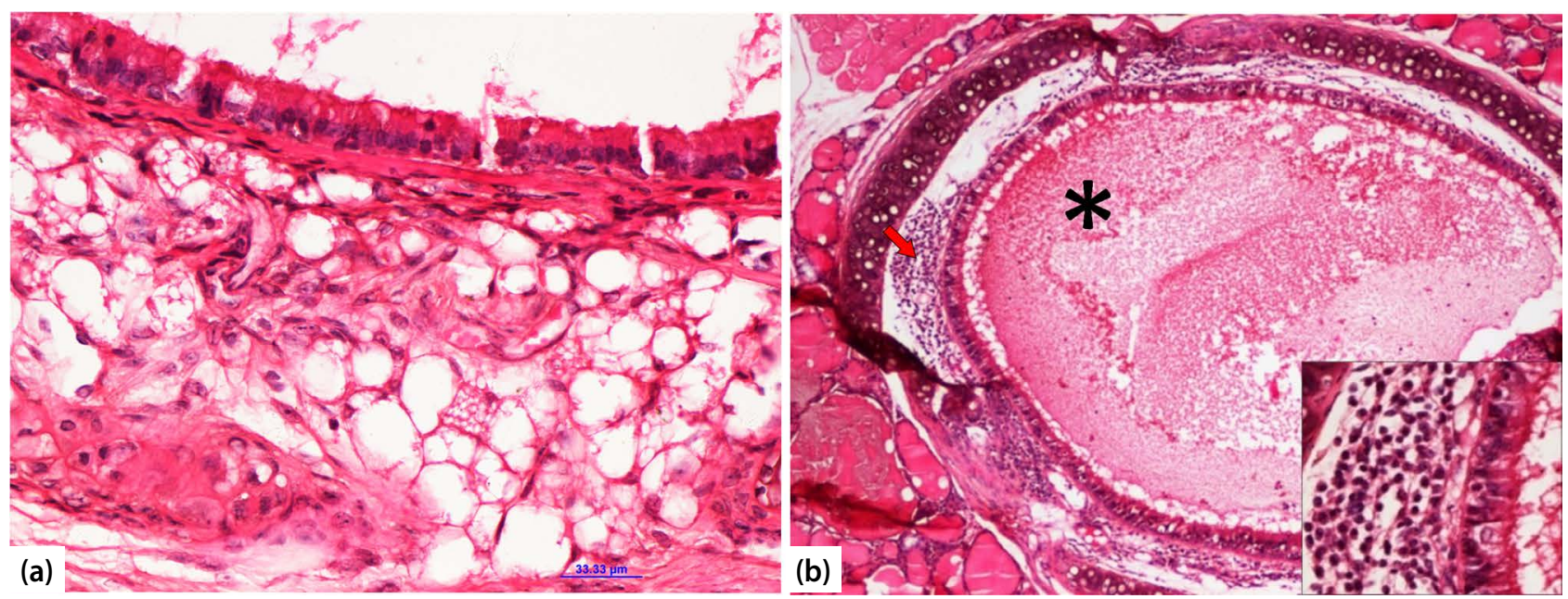

Fig. 7

Protection conferred by rgEIV immunization in BALB/c mice against EIV challenge

(a) Section of trachea from group B mouse (immunized challenged) at $5 \mathrm{dpc}$, showing intact ciliary epithelium (H\&E, 400x). (b) Group $\mathrm{C}$ mouse (unimmunized challenged) at $5 \mathrm{dpc}$, showing severe degeneration and deciliation of epithelium and submucosal infiltration (arrow) along with impacted lumen with exudate (asterisk) (H\&E 100x); Inset showing massive lymphocytic infiltration in submucosa, epithelial degeneration and deciliation (400x).

at $5 \mathrm{dpc}$, (Fig. 6d), which persisted till $7 \mathrm{dpc}$. The vaccinated group (group B) had significantly lower scores in development of gross lesions when compared to group $\mathrm{C}$, with level of significance being very high $(\mathrm{p}<0.001)$ at 3 and $5 \mathrm{dpc}$. The lesion scores on these intervals in group $C$ mice were $3.6 \pm 0.25$ and $3.8 \pm 0.20$, whereas for group B it was $1.6 \pm 0.25$ and $1.4 \pm 0.25$ (Fig. $5 b$ ).

Turbinates. Histopathological lesions in nasal turbinates in group B comprised of mild accumulation of mucus with mild goblet cell hyperplasia only at 3 and 5 $\mathrm{dpc}$, whereas group $\mathrm{C}$ showed severe rhinitis characterized by degeneration, denudation of ciliated epithelium, infiltration of lamina propria with inflammatory cells and lumen was impacted with accumulated lymphocytes and neutrophils admixed in mucus up to $7 \mathrm{dpc}$.

Trachea. The prominent microscopic lesions in tracheal sections of group $\mathrm{C}$ mice were severe epithelial necrosis, submucosal neutrophilic and lymphocytic infiltration along with impaction of lumen with necrotic tissue debris admixed with neutrophils and lymphocytes on 3 and 5 dpc(Fig. 7b). Squamous metaplasia of tracheal epithelium was observed $7 \mathrm{dpc}$ onwards. The tracheal sections from group B mice demonstrated minimal pathology with very mild inflammation (Fig. 7a). Only few sections showed focal denudation of tracheal epithelium, mild goblet cell hyperplasia and submucosal infiltration with neutrophils and lymphocytes, which was discernible till $3 \mathrm{dpc}$.

Lungs. The histopathological lesions in lungs were consistent with gross lesions described above. Mice in the group B were well protected from wild virus challenge and demonstrated minimal microscopic lung pathology in terms of intensity and duration. Group $\mathrm{C}$ mice exhibited lung lesions as early as $1 \mathrm{dpc}$, which persisted till $10 \mathrm{dpc}$. At $1 \mathrm{dpc}$, group $\mathrm{C}$ mice showed severely engorged blood vessels, thickening of interstitial tissue with neutrophil infiltration, focal necrosis of bronchial epithelium and its desquamation. Bronchiolar lumen was impeded with sloughed epithelial lining entrapped with mucus exudates admixed with neutrophils (Fig. 8b). In contrast, group B mice showed mild interstitial thickening, peribronchial neutrophilic infiltration and in few sections focal necrosis and sloughing of bronchial epithelium was observed (Fig. 8a).

At 3 dpc in group $C$ animals, interstitial tissue (particularly peribronchial) was thickened due to accumulation of edematous fluid along with neutrophilic infiltration (Fig. 8d), while appearance of macrophages was observed in group $B$ animals (Fig. 8c). From 5 to $7 \mathrm{dpc}$ in group $\mathrm{C}$ animals, macrophages proliferation with emergence of type II pneumocytes was main finding along with squamous metaplasia of bronchial epithelium in few sections (Fig. 8f-h, $8 \mathrm{~b}$ and $9 \mathrm{~b}$ ). At $5 \mathrm{dpc}$, significant reduction in severity of lesions was recorded in group B mice except noticeable mild bronchiolar epithelial degeneration (Fig. 9a). Lesions were reduced in intensity and focal in distribution at $10 \mathrm{dpc}$ in group $\mathrm{C}$ mice as well and overall lung pathology appeared to be normal by $14 \mathrm{dpc}$.

A highly significant reduction in histopathological lesion scoring in lungs was noticed in vaccinated group animals as compared to the positive control group $\mathrm{C}$ at 3 , 

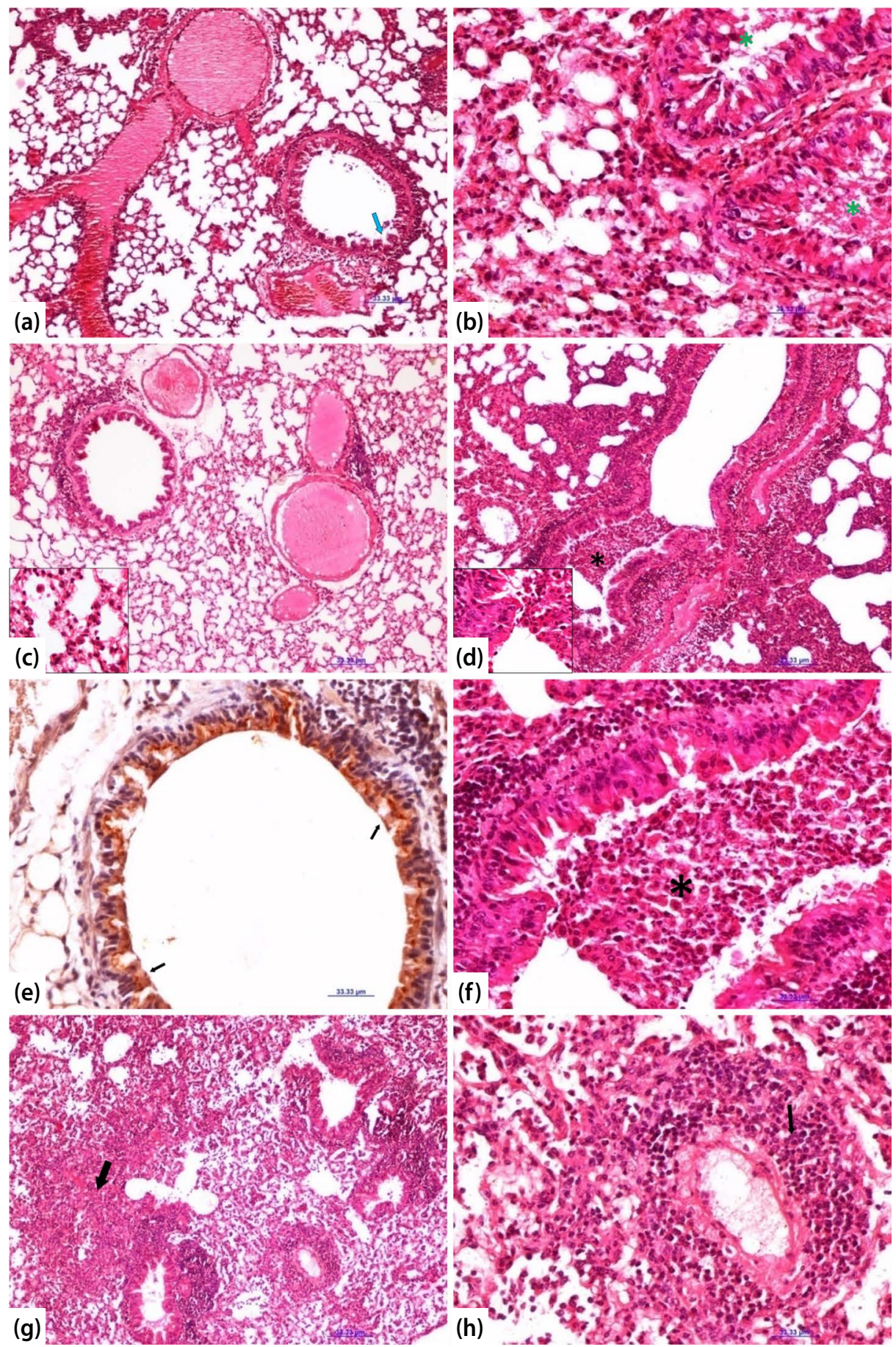

\section{(g)}

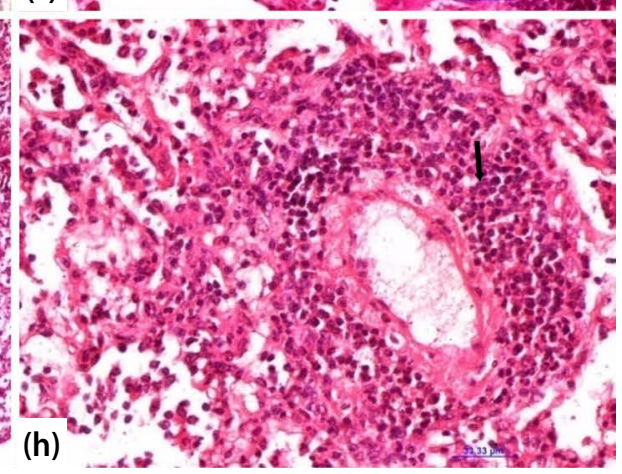

Fig. 8

Protection conferred by rgEIV immunization from lung histopathology in BALB/c mice after challenge with EIV (H3N8)

(a) Lung section from group B mouse at $1 \mathrm{dpc}$, showing apparently normal lung with mild peribronchial accumulation of inflammatory cells (arrow) (H\&E 100x). (b) group C mouse at $1 \mathrm{dpc}$ showing proliferative bronchiolitis, lumen impacted with exudate (asterisk) and surrounding tissue infiltrated with neutrophils and MNCs (H\&E 400x). (c) Group B mouse at 3 dpc, showing almost normal bronchiolar epithelium with congested blood vessels (H\&E 100x, Inset-400x). (d) Group C mouse at 3 dpc, showing severe necrotizing erosive bronchitis (asterisk) and emphysema (H\&E 100x). Inset: accumulation of neutrophils admixed with mucous in lumen 400x. (e) Group C mouse at 3 dpc, showing high EIV immunopositivity in bronchiolar epithelium (arrow) (IHC 400x). (f) Group C mouse at 5 dpc, showing severe bronchiolitis with exudate in lumen admixed with debris and neutrophils (asterisk) (H\&E 400x).(g) Group C mouse at 5 dpc showing interstitial pneumonia due to severe infiltration of inflammatory cells (arrow) (H\&E 100x). (h) Same section of Fig. G at higher magnification (400x) showing margination, transmigration and severe perivascular cuffing of lymphocytes mixed with neutrophils (arrow). 
Table 2. Mean histopathological lung lesions score at various intervals in group B and C mice after challenge with EIV

\begin{tabular}{|c|c|c|c|c|c|c|c|c|c|c|}
\hline \multirow{2}{*}{$\begin{array}{l}\text { Days } \\
\text { post } \\
\text { chal- } \\
\text { lenge }\end{array}$} & \multicolumn{2}{|c|}{$\begin{array}{l}\text { Cellular } \\
\text { infiltration }\end{array}$} & \multicolumn{2}{|c|}{$\begin{array}{l}\text { Interstitial } \\
\text { lesions }\end{array}$} & \multicolumn{2}{|c|}{$\begin{array}{l}\text { Peribronchial } \\
\text { and perivascular } \\
\text { infiltrations }\end{array}$} & \multicolumn{2}{|c|}{$\begin{array}{l}\text { Necrotic } \\
\text { changes }\end{array}$} & \multicolumn{2}{|c|}{$\begin{array}{l}\text { Bronchial } \\
\text { lesions }\end{array}$} \\
\hline & Group B & Group C & Group B & Group C & Group B & Group C & Group B & Group C & Group B & Group C \\
\hline 1 & $1.2 \pm 0.20^{*}$ & $2.4 \pm 0.25$ & $1.2 \pm 0.2$ & $1.8 \pm 0.20$ & $1.4 \pm 0.4$ & $1.8 \pm 0.37$ & $0.2 \pm 0.20^{*}$ & $1.8 \pm 0.20$ & $1.4 \pm 0.25$ & $2.2 \pm 0.20$ \\
\hline 3 & $1.6 \pm 0.25^{*}$ & $2.8 \pm 0.20$ & $1.4 \pm 0.40^{*}$ & $3.2 \pm 0.37$ & $2.2 \pm 0.37$ & $3 \pm 0.32$ & $1 \pm 0.32^{*}$ & $3.2 \pm 0.37$ & $1.8 \pm 0.20^{*}$ & $3.2 \pm 0.20$ \\
\hline 5 & $1.8 \pm 0.20$ & $2.6 \pm 0.25$ & $1.6 \pm 0.51^{*}$ & $3 \pm 0.32$ & $2.6 \pm 0.25$ & $2.8 \pm 0.20$ & $1.2 \pm 0.20^{*}$ & $2.8 \pm 0.37$ & $1.6 \pm 0.25^{*}$ & $3 \pm 0.55$ \\
\hline 7 & $1.6 \pm 0.25^{*}$ & $2.6 \pm 0.25$ & $1.2 \pm 0.37^{*}$ & $2.8 \pm 0.37$ & $2 \pm 0$ & $2.6 \pm 0.25$ & $0.8 \pm 0.20$ & $1.8 \pm 0.37$ & $0.8 \pm 0.20^{*}$ & $2.8 \pm 0.37$ \\
\hline 10 & $1.4 \pm 0.25^{*}$ & $2.4 \pm 0.25$ & $1 \pm 0.32^{*}$ & $2.4 \pm 0.25$ & $1.6 \pm 0.25$ & $2.4 \pm 0.40$ & $0.8 \pm 0.20$ & $1.4 \pm 0.25$ & $0.6 \pm 0.25^{*}$ & $1.8 \pm 0.58$ \\
\hline 14 & $1.2 \pm 0.2$ & $1.8 \pm 0.20$ & $0.2 \pm 0.20^{*}$ & $1.8 \pm 0.20$ & $0.4 \pm 0.25$ & $1.4 \pm 0.40$ & $0.2 \pm 0.20$ & $0.6 \pm 0.25$ & $0 \pm 0$ & $0.8 \pm 0.20$ \\
\hline
\end{tabular}

Each value represents mean \pm SEM $(n=5)$. *indicates significant difference $(p<0.05)$ between groups in the same row in two-way ANOVA, Bonnferoni post hoc test.

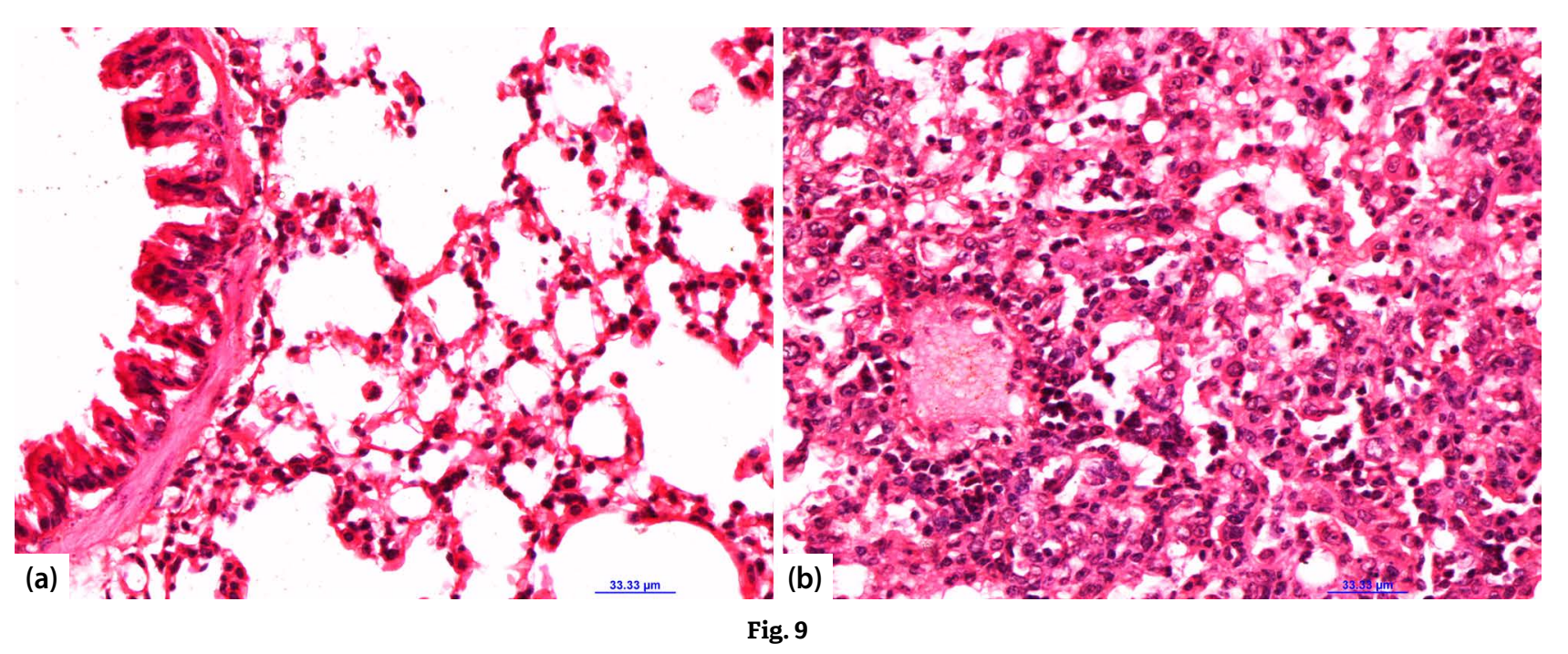

Lung sections at 7 days post challenge

(a) Group B mouse showing almost normal appearance (H\&E 100x). (b) Group C mouse showing extensive interstitial infiltration of inflammatory cells (H\&E 100x). Inset: Severe proliferation of macrophages (1000x).

5 and $7 \mathrm{dpc}(\mathrm{p}<0.01)$ (Table 2). The highest mean total histopathological lesion score was recorded at $5 \mathrm{dpc}$, which was almost double for group C $(3.4 \pm 0.4)$ in comparison to group B $(1.8 \pm 0.2)$.

Localization of EIV antigen in tissue by immunohistochemistry

Strong positivity for EIV antigen in epithelial lining of turbinates, trachea, bronchi, bronchioles, macrophages in lamina propria, peribronchiolar and interstitial tissue of lungs was detectable indirect immunoperoxidase test up to $5 \mathrm{dpc}$ in group $\mathrm{C}$ mice (Fig. 7e). The reduction in reaction was noticed at $7 \mathrm{dpc}$ and the reaction was very weak by 10 dpc. In immunized mice, the EIV antigen positivity was detectable until $5 \mathrm{dpc}$ in only epithelial linings of trachea and bronchi with weak intensity.

The rgEIV immunization resulted in reduced residual virus in trachea and lungs in comparison to control mice

EIV could not be isolated in detectable quantities from nasal washing and lung tissue in vaccinated mice (group B) even on $1 \mathrm{dpc}$; whereas in group $\mathrm{C}$, virus shedding from the nasopharynx could be detected with the titer (at 1dpc) of $10^{5.5} \mathrm{EID}_{50}$ per $\mathrm{ml}$ of nasal washing that persisted up to 5 dpc $\left(10^{1.5} \mathrm{EID}_{50}\right.$ per $\left.\mathrm{ml}\right)$ (Fig. 10a). The residual EIV virus in lung tissues of group $\mathrm{C}$ mice $(1 \mathrm{dpc})$ was detected with a titer of $10^{3.75} \mathrm{EID}_{50}$ per gram of tissue, which subsequently 
(a)

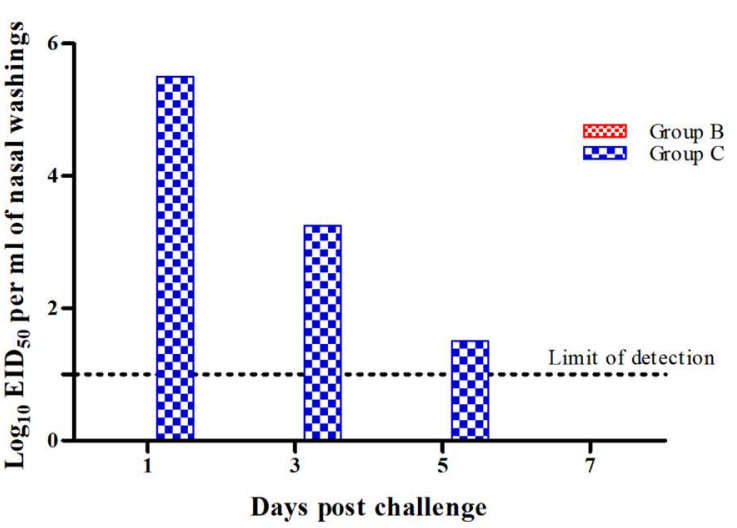

(b)

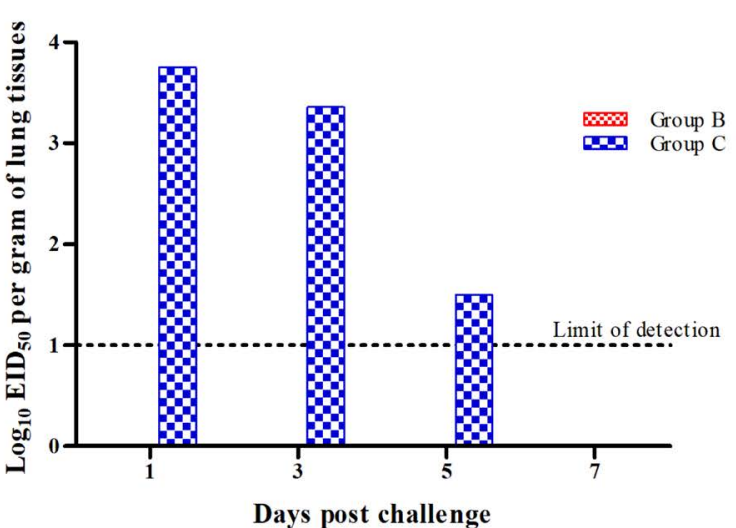

Fig. 10

EIV titers $\left(\log _{10}\right.$ Mean EID 50$)$ in nasal washing and lungs after EIV challenge

(a) EIV shedding in nasal washings of mice from group $B$ (immunized challenged) and $C$ (unimmunized challenged) mice at various intervals after challenge with EIV. (b) Residual EIV in lungs of mice from group B and C at various intervals after challenge with EIV.

Table 3. Quantification of EIV shedding in nasal washings/residual virus in lungs by qRT-PCR in group B and C mice at various intervals after challenge with EIV

\begin{tabular}{|c|c|c|c|c|c|c|c|c|}
\hline \multirow{3}{*}{$\begin{array}{c}\text { Days } \\
\text { post } \\
\text { challenge }\end{array}$} & \multicolumn{4}{|c|}{ Nasal washings } & \multicolumn{4}{|c|}{ Lung tissues } \\
\hline & \multicolumn{2}{|c|}{ EIV viral RNA copy numbers } & \multicolumn{2}{|c|}{ Ct values } & \multicolumn{2}{|c|}{ EIV viral RNA copy numbers } & \multicolumn{2}{|c|}{ Ct values } \\
\hline & Group B & Group C & Group B & Group C & Group B & Group C & Group B & Group C \\
\hline 1 & $600.6 \pm 71.8^{*}$ & $12056.6 \pm 2643.7$ & $33.5 \pm 0.78^{\#}$ & $23.5 \pm 0.68$ & $5711.2 \pm 628.2^{*}$ & $14581 \pm 3512.4$ & $30 \pm 1.01^{\#}$ & $22.4 \pm 0.26$ \\
\hline 3 & $1210.2 \pm 56.5^{*}$ & $10602.5 \pm 2856.8$ & $32.9 \pm 0.87^{\#}$ & $24.6 \pm 0.43$ & $1421.1 \pm 263.2^{*}$ & $11002 \pm 2436.7$ & $33.5 \pm 0.91^{\#}$ & $25.5 \pm 0.69$ \\
\hline 5 & $16.2 \pm 0.9$ & $2011.3 \pm 123.2$ & $36.1 \pm 0.98^{\#}$ & $31.6 \pm 0.78$ & $\mathrm{ND}^{*}$ & $6562 \pm 798.8$ & $\mathrm{ND}^{\#}$ & $29.1 \pm 0.61$ \\
\hline 7 & ND & $621.2 \pm 43.1$ & $\mathrm{ND}^{\#}$ & $33.4 \pm 1.1$ & $\mathrm{ND}^{*}$ & $4235 \pm 460.6$ & $\mathrm{ND}^{\#}$ & $31.7 \pm 0.98$ \\
\hline 10 & ND & ND & ND & ND & ND & $1121 \pm 51.7$ & $\mathrm{ND}^{\#}$ & $34.2 \pm 1.05$ \\
\hline 14 & $600.6 \pm 71.8^{*}$ & $12056.6 \pm 2643.7$ & ND & ND & ND & ND & ND & ND \\
\hline
\end{tabular}

Each value represents mean \pm SEM $(n=5)$. *and \#indicates significant difference $(p<0.01)$ between groups in the same row in two-way ANOVA, Bonnferoni post hoc test. ND = not detected.

decreased to $10^{3.36} \mathrm{EID}_{50}$ and $10^{1.5} \mathrm{EID}_{50}$ on 3 and $5 \mathrm{dpc}$, respectively (Fig. 10b). No live virus could be detected in nasal washing and lung tissue of group $A$ and $D$ mice at any of the intervals.

\section{Quantification of EIV shedding by qRT-PCR}

Residual virus isolation studies in embryonated eggs were further substantiated by quantification of EIV RNA copy number by qRT-PCR. Immunization with rgEIV resulted in significant reduction $(\mathrm{p}<0.001)$ of EIV in nasal washing and lung tissue. The estimated EIV RNA copy numbers at $3 \mathrm{dpc}$ in group B were $1210.2 \pm 56.5$ and $1421.1 \pm 263.2$ in nasal washings and lungs, respectively and $10602.5 \pm 2856.8$ and $11002 \pm 2436.7$ for group C (Table 3). The virus shedding further decreased at $5 \mathrm{dpc}$ (in group B $16.2 \pm 0.9$ in nasal washings only and in group C
$2011.3 \pm 123.2$ and $6562 \pm 798.8$ in nasal washings and lungs, respectively). The Ct values also corresponded to copy numbers (Table 3).

\section{Discussion}

Continuous antigenic drift in EIV, like other IAVs, makes the vaccines less effective, necessitating continuous harmonization of vaccines with circulating strains. The reverse genetics platform has been employed as an important tool to aid in the quick substitution of $\mathrm{HA}$ and NA genes of influenza virus and can help in faster harmonization of vaccines without the hassles of strain substitution. Present investigations are an attempt to demonstrate the protective efficacy of a recombinant EIV (having HA and NA genes of H3N8 EIV belonging to 
Florida clade 2 sub-lineage) generated in the backbone of A/WSN/33 (H1N1) in a murine model. The murine challenge model has been successfully developed in our laboratory previously for pathological studies as well as vaccine efficacy studies (Pavulraj et al., 2015; 2017).

Humoral immune responses following immunization and post challenge were assayed employing HAI and indirect ELISA. Group A (immunized and mock challenged) and $B$ (immunized and challenged with wild EIV) mice induced significantly high HAI titers $(140.8 \pm 31.35)$, which were well above the recommended optimum protective titer of 1:64 (OIE, 2017). Post challenge mean HAI antibody titer in group B animals rose to 921.6 \pm 102.4 (14 $\mathrm{dpc}$ ) and commensurated with rise in ELISA antibody titers. The rise of HAI titer following vaccination with the recombinant virus is in consonance with that recorded for inactivated EIV vaccine, live attenuated vaccine and a live cold-adapted vaccine (Cullinane et al., 2001; Enian et al., 2011; Yamanaka et al., 2011; Paillot et al., 2013; Baz et al., 2015; Kim et al., 2015; Pavulraj et al., 2017; Rodriguez et al., 2018). In another study conducted in mice immunized with inactivated recombinant H3N2 (A/Swine/Guangdong/164/06 (H3N2)-GD/PR8) virus, a reciprocal HAI titer of 160 and ELISA antibody titer of $10^{5}$ post immunization provided adequate protection against challenge with homologous H3N2 SwIV (Wen et al., 2014). The higher hemagglutinin antibody response generated by rgEIV vaccine led to neutralization of EIV upon challenge, as evident from lower amount of residual virus in lungs and nasopharynx. The anti-hemagglutinin antibodies have been strongly correlated with the neutralizing antibodies against influenza virus in human (Hobson et al.,1972). Further, the isotyping of antibodies revealed IgG1 to be predominant followed by IgG2a, IgG2b, IgG3 and IgM. This indicates triggering of comparatively stronger Th2-driven response and has been described in other influenza virus vaccine studies in mice (Moran et al., 1999; Soema et al., 2014; Pavulraj et al., 2017). In contrast, Szyszko et al. (2006) observed higher IgG2a levels after primary immunization followed by increased level of IgG1 in booster immunization. The higher IgG1 response after primary immunization may be due to the addition of aluminium hydroxide gel adjuvant in our vaccine preparation, which is a strong inducer of Th2-driven immune response (Sangster et al., 2003; Lindblad, 2004; Ko et al., 2016). Further, a sufficient rise in IgG2a antibodies is indicative of activation of complement (Neuberger and Rajewsky, 1981) and contributes towards antibody-dependent cytotoxic immunity (Huber et al., 2006). The immune response to vaccine was correlated with cytokine profiles, which were estimated by measuring the gene level expression of IFN- $\gamma$ and IL-2 for Th1-type response; IL-4 for Th2-type response; and IL-6 as Th2-type marker and pro-inflammatory cytokine. The increased expression of mRNA level of IL-4 ( 2 fold at $3 \mathrm{dpc}$ and $\sim 5$ fold at $14 \mathrm{dpc}$ ) observed in primed mice after challenge with wild EIV can be correlated with generation of Th2-driven immune responses (Moran et al., 1999; Szyszko et al., 2006). A surge in IL-6 levels (post immunization 4.5 fold; post challenge $\sim 2$ to 6 fold) was observed. The IL- 6 has been documented to influence the antibody production by B cells through up-regulation of IL-21 production by CD4+ T cells (Hirano et al., 1985; Dienz et al., 2009) and also helps in production of antigen-specific IgG subclasses (Kopf et al., 1998). Thus, robust humoral immune response by the rgEIV can be attributed to production of IL- 4 and IL- 6 cytokines. Further, an increased expression of Th1 type cytokines (IFN- $\gamma$ : 64 fold and IL-2: 8 fold) in spleen was observed at $42 \mathrm{dpi}$, which is required for activation of macrophages, natural killer cells and cytotoxic cells for virus clearance (Topham et al., 1997; Lin and Leonard, 2003; Schreiber and Schreiber, 2003). The adequate hemagglutinating antibody titers and sufficient spike in cytokine responses (IFN- $\gamma$, IL-2, IL-4 and IL-6) invoked mixed Th1 and Th2 responses and led to early clearance and significantly lower residual virus titers in nasal washes and lung tissue, which was validated further by quantification of viral RNA copy numbers by qRT-PCR at various intervals. These findings were in consonance with vaccine efficacy studies conducted with inactivated whole EIV in murine model as well as horses (Heldens et al., 2010; Paillot et al., 2013a; 2013b; Rodriguez et al., 2018). Other recombinant influenza A viruses, viz. H5N1 (highly pathogenic avian influenza virus) in poultry and H1N1 in murine model have shown effective protection against challenge (Uchida et al., 2014; Nogales et al., 2016).

Immunization with rgEIV successfully protected mice from clinical disease and loss of body weight, which were otherwise severe in unimmunized challenged mice $(-6.92 \pm 0.96 \%$ at $6 \mathrm{dpc})$. Clinical signs and their duration corroborated with intensity of gross lesions in lungs, which were very low in immunized mice compared to positive control. Protection against histological lesions was apparent in immunized mice as evident from low intensity and shorter duration of lesions in lungs. The macrophages were discernible in lungs at an early day (3 dpc) as compared to unimmunized mice (at $5 \mathrm{dpc}$ ). Their role has been described to be important in reducing viral load in lungs and controlling early stage of infection (Pribul et al., 2008). Elevated level of IL-6 observed during challenge period in immunized mice is critical for increasing macrophage recruitment to the lung and enhancing phagocytosis of virus-infected cells by macrophages(Yang et al., 2017). Above findings are further substantiated with an overall significantly low lung histological score and less intense EIV antigen distribution demonstrated by immunohistochemistry in epithelial lining cells of nasal 
turbinates, trachea, bronchi, bronchioles and macrophages for small time span underlying early clearance of virus in immunized group. These findings were in consonance with previous influenza virus studies viz., H1N1 (Shirey et al., 2013; Leung et al., 2014); H5N1 (Park et al., 2014; Cheng et al., 2016); H3N2 (Richt et al., 2006), canine and equine isolates of H3N8 (Castleman et al., 2010; Begg et al., 2011; Muranaka et al., 2012; Pavulraj et al., 2015; 2017).

It can be concluded from our study that inactivated rgEIV vaccine candidate having $\mathrm{HA}$ and NA genes of H3N8 EIV belonging to Florida clade 2 sublineage in the backbone of A/WSN/33 (H1N1)\} generated strong protective humoral response and surge in cytokines (IFN- $\gamma$, IL-2, IL-4 and IL-6) producing mixed Th1 and Th2 responses, which led to rapid clearance of virus and thereby reduction in clinical signs and disease pathology in experimental mice. The protection was comparable to that observed with inactivated wild whole virus vaccine in murine model. Thus, reverse genetics-based approach can be an effective tool to update EIV vaccine by replacing HA and NA genes of circulating virus for quick harmonization of vaccines in the state of exigency.

Acknowledgments. We are thankful to the ICAR-NRCE and LUVAS, Hisar for providing infrastructural facility for the study. Thanks are due to Mukesh Chand, Subhash Chander and Ramesh for their technical support and kind help during the experimentation.

\section{References}

Andino R, Domingo E (2015): Viral quasi species. Virology 479, 46-51. https://doi.org/10.1016/i.virol.2015.03.022

Baz M, Paskel M, Matsuoka Y, Zengel J, Cheng X, Treanor JJ, Jin $\mathrm{H}$, Subbarao K (2015): A live attenuated equine H3N8 influenza vaccine is highly immunogenic and efficacious in mice and ferrets. J. Virol. 89, 1652-1659. https:// doi.org/10.1128/JVI.02449-14

Begg AP, Reece RL, Hum S, Townsend W, Gordon A, Carrick $\mathrm{J}$ (2011): Pathological changes in horses dying with equine influenza in Australia, 2007. Aust. Vet. J. 89, 19-22. https://doi.org/10.1111/j.1751-0813.2011.00731.x

Bhatia S, Khandia R, Sood R, Bhat S, Siddiqui A, Jahagirdhar G, Mishra S, Mishra A, Pateriya AK, Kulkarni DD (2016): Reverse genetics based rgH5N2 vaccine provides protection against high dose challenge of H5N1 avian influenza virus in chicken. Microb. Pathog. 97, 172-177. https://doi.org/10.1016/i.micpath.2016.06.011

Castleman WL, Powe JR, Crawford PC, Gibbs EP, Dubovi EJ, Donis RO, Hanshaw D (2010): Canine H3N8 influenza virus infection in dogs and mice. Vet. Pathol. 47, 507517. https://doi.org/10.1177/0300985810363718

Cheng T, Wang X, Song Y, Tang X, Zhang C, Zhang H, Jin X, Zhou D (2016): Chimpanzee adenovirus vector-based avian influenza vaccine completely protects mice against lethal challenge of H5N1. Vaccine 34, 4875-4883. https:// doi.org/10.1016/i.vaccine.2016.08.066

Cox NJ, Subbarao K (2000). Global epidemiology of influenza: past and present. Annu. Rev. Med. 51, 407-421. https:// doi.org/10.1146/annurev.med.51.1.407

Cullinane A, Weld J, Osborne M, Nelly M, McBride C, Walsh C (2001): Field studies on equine influenza vaccination regimes in thoroughbred foals and yearlings. Vet. J.161, 174-185. https://doi.org/10.1053/tvil.2000.0546

Dienz O, Eaton SM, Bond JP, Neveu W, Moquin D, Noubade R, Briso EM, Charland C, Leonard WJ, Ciliberto G, Teuscher C (2009): The induction of antibody production by IL- 6 is indirectly mediated by IL-21 produced by CD4+ T cells. J. Exp. Med. 206, 69-78. https://doi. org/10.1084/jem.20081571

Elton D, Cullinane A (2013): Equine influenza: Antigenic drift and implications for vaccines. Equine Vet. J. 45, 768-769. https://doi.org/10.1111/evj.12148

Enian EM, Zeinab ST, Al-lmam SH (2011): Immune Response of Pregnant Mares and their Foals for Inactivated Equine Influenza Vaccine. Int. J. Virol. 7, 210-214. https://doi. org/10.3923/ijv.2011.210.214

Garner MG, Cowled B, East IJ, Moloney BJ, Kung NY (2011): Evaluating the effectiveness of early vaccination in the control and eradication of equine influenza - A modelling approach. Prev. Vet. Med. 99, 15-27. https:// doi.org/10.1016/j.prevetmed.2010.02.007

Gildea S, Quinlivan M, Arkins S, Cullinane A (2012): The molecular epidemiology of equine influenza in Ireland from 2007-2010 and its international significance. Equine Vet. J.44,387-392.https://doi.org/10.1111/j.20423306.2011.00472.x

Heldens JG, Pouwels HG, Derks CG, Van de Zande SM, Hoeijmakers MJ (2010): Duration of immunity induced by an equine influenza and tetanus combination vaccine formulation adjuvanted with ISCOM-Matrix. Vaccine 28, 6989-6996. https://doi.org/10.1016/j.vaccine.2010.08.043

Hirano T, Taga T, Nakano N, Yasukawa K, Kashiwamura S, Shimizu K, Nakajima K, Pyun KH, Kishimoto T (1985): Purification to homogeneity and characterization of human B-cell differentiation factor (BCDF or BSFp-2). Proc. Natl. Acad. Sci. USA 82, 5490-5494. https://doi. org/10.1073/pnas.82.16.5490

Hobson D, Curry RL, Beare AS, Ward-Gardner A (1972): The role of serum haemagglutination-inhibiting antibody in protection against challenge infection with influenza A2 and B viruses. Epidemiol. Infect. 70, 767-77. https:// doi.org/10.1017/S0022172400022610

Hoffmann E, Neumann G, Kawaoka Y, Hobom G, Webster RG (2000): A DNA transfection system for generation of influenza A virus from eight plasmids. Proc. Natl. Acad. Sci. USA 97, 6108-6113. https://doi.org/10.1073/ pnas.100133697

Huber VC, McKeon RM, Brackin MN, Miller LA, Keating R, Brown SA, Makarova N, Perez DR, MacDonald GH, McCullers JA (2006): Distinct contributions of vaccine-induced 
immunoglobulin G1 (IgG1) and IgG2a antibodies to protective immunity against influenza. Clin. Vaccine Immunol. 13, 981-990. https://doi.org/10.1128/ CVI.00156-06

Kim EJ, Kim BH, Yang S, Choi EJ, Shin YJ, Song JY, Shin YK (2015): Antibody responses after vaccination against equine influenza in the Republic of Korea in 2013. J. Vet. Med. Sci. 77, 1517-1521. https://doi.org/10.1292/ jvms.15-0192

Ko EJ, Lee YT, Kim KH, Jung YJ, Lee Y, Denning TL, Kang SM (2016): MF59 adjuvant effects on inducing isotypeswitched IgG antibodies and protection after immunization with T-dependent influenza virus vaccine in the absence of CD4+ T cells. J. Virol. 90, 6976-6988. https://doi.org/10.1128/JVI.00339-16

Kopf M, Herren S, Wiles MV, Pepys MB, Kosco-Vilbois MH (1998): Interleukin 6 influences germinal center development and antibody production via a contribution of C3 complement component. J. Exp. Med. 188, 1895-1906. https://doi.org/10.1084/jem.188.10.1895

Laver WG, Valentine RC (1969): Morphology of the isolated hemagglutinin and neuraminidase subunits of influenza virus. Virology 38, 105-119. https://doi. org/10.1016/0042-6822(69)90132-9

Leung YC, Nicholls JM, Ho CK, Sia SF, Mok CK, Valkenburg SA, Cheung P, Hui KP, Chan RW, Guan Y, Akira SH (2014): Highly pathogenic avian influenza A H5N1 and pandemic H1N1 virus infections have different phenotypes in Toll-like receptor 3 knockout mice. J. Gen. Virol. 95, 1870-1879. https://doi.org/10.1099/ vir.0.066258-0

Lin Y-X, Leonard WJ (2003). Interleukin-2. In Thomson AW, Lotze MT (Eds.). The Cytokine Handbook. Academic Press, San Diego, CA, pp. 167-200. https://doi.org/10.1016/ B978-012689663-3/50012-0

Lindblad EB (2004): Aluminium adjuvants-in retrospect and prospect. Vaccine 22, 3658-3668. https://doi. org/10.1016/j.vaccine.2004.03.032

Lu Z, Chambers TM, Boliar S, Branscum AJ, Sturgill TL, Timoney PJ, Reedy SE, Tudor LR, Dubovi EJ, Vickers ML, Sells $S$ (2009): Development and evaluation of one-step TaqMan real-time reverse transcription-PCR assays targeting nucleoprotein, matrix, and hemagglutinin genes of equine influenza virus. J. Clin. Microbiol. 47, 3907-3913. https://doi.org/10.1128/JCM.00598-09

Moran TM, Park H, Fernandez-Sesma A, Schulman JL (1999): Th2 responses to inactivated influenza virus can be converted to Th1 responses and facilitate recovery from heterosubtypic virus infection. J. Infect. Dis. 180, 579-585. https://doi.org/10.1086/314952

Muranaka M, Yamanaka T, Katayama Y, Niwa H, Oku K, Matsumura T, Oyamada T(2012): Time-related pathological changes in horses experimentally inoculated with equine influenza a virus. J. Equine Sci.23,17-26. https:// doi.org/10.1294/jes.23.17

Neuberger MS, Rajewsky K (1981): Activation of mouse complement by monoclonal mouse antibodies. Eur. J. Immunol.11,1012-1016. https://doi.org/10.1002/eji.1830111212
Neumann G, Fujii K, Kino Y, Kawaoka Y (2005): An improved reverse genetics system for influenza A virus generation and its implications for vaccine production. Proc. Natl. Acad. Sci. USA 102,16825-16829. https://doi. org/10.1073/pnas.0505587102

Nogales A, DeDiego ML, Topham DJ, Martínez-Sobrido L (2016): Rearrangement of influenza virus spliced segments for the development of live attenuated vaccines. J. Virol.90,6291-6302.https://doi.org/10.1128/JVI.00410-16

OIE Expert Surveillance Panel on Equine Influenza Vaccine Composition, OIE Headquarters, 22 March 2017. http://www.oie.int/en/our-scientific-expertise/ specific-information-and-recommendations/equineinfluenza/.

Paillot R, Prowse L, Montesso F, Huang CM, Barnes H, Escala $\mathrm{J}$ (2013a). Whole inactivated equine influenza vaccine: Efficacy against a representative clade 2 equine influenza virus, IFN gamma synthesis and duration of humoral immunity. Vet. Microbial. 162, 396-407. https://doi.org/10.1016/i.vetmic.2012.10.019

Paillot R, Prowse L, Montesso F, Stewart B, Jordon L, Newton JR, Gilkerson JR (2013b): Duration of equine influenza virus shedding and infectivity in immunised horses after experimental infection with EIV A/eq2/ Richmond/1/07. Vet. Microbiol.166, 22-34. https://doi. org/10.1016/j.vetmic.2013.04.027

Paillot R (2014). A systematic review of recent advances in equine influenza vaccination. Vaccines 2, 797-831. https://doi.org/10.3390/vaccines2040797

Park EH, Song BM, Yum J, Kim JA, Oh SK, Kim HS, Cho GJ, Seo SH (2014): Protective efficacy of a single dose of baculovirus hemagglutinin-based vaccine in chickens and ducks against homologous and heterologous H5N1 virus infections. Viral Immunol. 27, 449-462. https:// doi.org/10.1089/vim.2014.0029

Pavulraj S, Bera BC, Joshi A, Anand T, Virmani M, Vaid RK, Shanmugasundaram K, Gulati BR, Rajukumar K, Singh R, Misri J (2015): Pathology of Equine Influenza virus (H3N8) in Murine Model. PloS One 10, e0143094. https://doi.org/10.1371/journal.pone.0143094

Pavulraj S, Virmani N, Bera BC, Joshi A, Anand T, Virmani M, Singh R, Singh RK, Tripathi BN (2017): Immunogenicity and protective efficacy of inactivated equine influenza (H3N8) virus vaccine in murine model. Vet. Microbiol. 210, 188-196. https://doi.org/10.1016/i. vetmic.2017.08.013

Pribul PK, Harker J, Wang B, Wang H, Tregoning JS, Schwarze J, Openshaw PJ(2008): Alveolar macrophages are a major determinant of early responses to viral lung infection but do not influence subsequent disease development. J. Virol. 82, 4441-4448. https://doi.org/10.1128/ JVI.02541-07

Reed LJ, Muench H (1938): A simple method of estimating fifty per cent endpoints. Am. J. Epidemiol. 27, 493-497. https://doi.org/10.1093/oxfordjournals.aje.a118408

Richt JA, Lekcharoensuk P, Lager KM, Vincent AL, Loiacono CM, Janke BH, Wu WH, Yoon KJ, Webby RJ, Solórzano A, García-Sastre A (2006): Vaccination of pigs against 
swine influenza viruses by using an NS1-truncated modified live-virus vaccine. J. Virol. 80, 11009-11018. https://doi.org/10.1128/JVI.00787-06

Rodriguez L, Reedy S, Nogales A, Murcia PR, Chambers TM, Martinez-Sobrido L (2018): Development of a novel equine influenza virus live-attenuated vaccine. Virology 516, 76-85. https://doi.org/10.1016/j.virol.2018.01.005

Sangster MY, Riberdy JM, Gonzalez M, Topham DJ, Baumgarth N, Doherty PC (2003): An early CD4+ T cell-dependent immunoglobulin a response to influenza infection in the absence of key cognate T-B interactions. J. Exp. Med. 198, 1011-1021. https://doi.org/10.1084/ jem.20021745

Schreiber GH, Schreiber RD (2003): Interferon-gamma. In Thomson AW, Lotze MT (Eds.): The Cytokine Handbook. Academic Press, San Diego, CA, pp. 567-602. https:// doi.org/10.1016/B978-012689663-3/50028-4

Shirey KA, Lai W, Scott AJ, Lipsky M, Mistry P, Pletneva LM, Karp CL, McAlees J, Gioannini TL, Weiss J, Chen WH (2013): The TLR4 antagonist Eritoran protects mice from lethal influenza infection. Nature 497, 498. https://doi. org/10.1038/nature12118

Soema PC, Willems GJ, van Twillert K, van de Wijdeven G, Boog CJ, Kersten GF, Amorij JP (2014): Solid bioneedle-delivered influenza vaccines are highly thermostable and induce both humoral and cellular immune responses. PloS One 9, e92806. https://doi.org/10.1371/journal. pone.0092806

Szyszko E, Brokstad K, Cox RJ, Hovden AO, Madhun A, Haaheim LR (2006): Impact of influenza vaccine formulation with a detailed analysis of the cytokine response.
Scand. J. Immunol. 64, 467-475. https://doi.org/10.1111/ j.1365-3083.2006.01805.x

Topham DJ, Tripp RA, Doherty PC (1997): CD8 + T cells clear influenza virus by perforin or Fas-dependent processes. J. Immunol. 159, 5197-5200.

Uchida Y, Takemae N, Saito T (2014): Application of reverse genetics for producing attenuated vaccine strains against highly pathogenic avian influenza viruses. J. Vet. Med. Sci. 76, 1111-1117. https://doi.org/10.1292/ jvms.13-0620

Virmani N, Bera BC, Gulati BR, Karuppusamy S, Singh BK, Vaid RK, Kumar S, Kumar R, Malik P, Khurana SK, Singh RK (2010): Descriptive epidemiology of equine influenza in India (2008-2009): temporal and spatial trends. Vet. Ital. 46, 449-458.

Wen F, Ma JH, Yu H, Yang FR, Huang M, Zhou YJ, Li ZJ, Tong GZ (2014): Protective efficacy of a high-growth reassortant swine H3N2 inactivated vaccine constructed by reverse genetic manipulation. J. Vet. Sci. 15, 381-388. https://doi.org/10.4142/jvs.2014.15.3.381

Yamanaka T, Bannai H, Nemoto M, Tsujimura K, Kondo T, Matsumura T (2011): Antibody responses induced by Japanese whole inactivated vaccines against equine influenza virus (H3N8) belonging to Florida sublineage clade 2. J. Vet. Med. Sci. 73, 483-485. https://doi. org/10.1292/jvms.10-0408

Yang ML, Wang CT, Yang SJ, Leu CH, Chen SH, Wu CL, Shiau AL (2017): IL-6 ameliorates acute lung injury in influenza virus infection. Sci. Rep. 7, 43829. https://doi. org/10.1038/srep 43829 